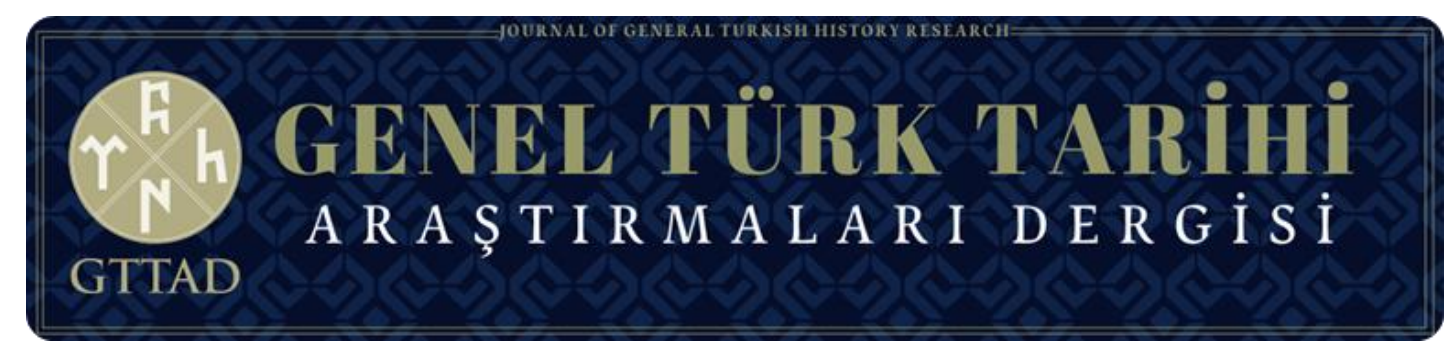

Cilt/Volume 4, Sayı/Issue 7, Ocak/January 2022, ss. 167-188.

Geliş Tarihi-Received Date: 18.12.2021 Kabul Tarihi-Accepted Date: 07.01.2022

ARAŞTIRMA MAKALESİ - RESEARCH ARTICLE

WAS THERE ANTIQUITIES LAW AND REGULATIONS BEFORE THE ÂSÂR-I ATÎKA

NIZÂMNÂME OF 1869?

(DCEMIL ÇELIK*

doi) $10.53718 / \mathrm{gttad} .1038303$

\begin{abstract}
This article aims to address the question of law, administrative rules and custom concerning the antiquities in Ottoman territory in the period before the $13^{\text {th }}$ of February 1869 when the "Âsâr-1 Atîka Nizâmnâme," came into force, which has repeatedly been said to be the Ottoman state's first regulation of archaeological resources, if this is not said in respect to that promulgated in 1874, or even that of 1884, which has repeatedly been the case in the modern works on this subject published over the past thirty years. The resources employed in this research include previously unpublished Ottoman archival material concerning antiquities, addressing the matter of Ottoman antiquities regulations, as there are Ottoman Emirnâme, and administrative regulations, that include the forbidding of the export of antiquities from Ottoman territory, and placing limits upon foreign antiquarian research and on digging/excavation at ancient sites, as elsewhere in Ottoman territory in the period before 1869. The regulation of 1869 simply codified the earlier legal administrative practice concerning antiquities. For example, on the $30^{\text {th }}$ of August, 1852, Edhem Paşa, was warned that care should be taken to prevent the selling of antiquities to foreigners; in a document dated $4^{\text {th }}$ of May, 1865, it is seen that certain rules should be followed in excavation permits related to historical artifacts in the Ottoman State.
\end{abstract}

The evidence from non-Ottoman sources clearly shows that Ottoman law, rule and custom forbidding the export of antiquities without explicit permission was certainly in force in the $17^{\text {th }}$ century, more than two centuries before the era of Tanzimat. In 1623 the English ambassador to the Porte stated there was at that time, both law and custom forbidding the removal of antiquities from Ottoman territory. In consequence, the ambassador stated that secrecy and bribery were to be employed to remove antiquities from Ottoman territory. These same methods were likewise advised in publications of the the $18^{\text {th }}$ and $19^{\text {th }}$ centuries.

This article suggests that a reason for the repeated emphasis in the modern literature upon the Âsar- $\iota$ Atîka Nizâmnâme of 1869, of 1874 and of 1884, is that this serves in effect to legalize a rather large quantity of antiquities that were removed illegally, through secrecy and bribery, without permission, from Ottoman territory in the period before 1869 which are today in a wide variety of museums and collections abroad.

Keywords: Ottoman Antiquities Law, Administrative Rules and Customs, Stolen Antiquities, Secrecy and Corruption.

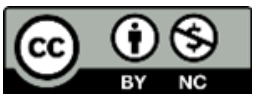

*Dr., TÜRKIYE, E-Posta: cemilcelik736@yahoo.com.tr, ORCID ID: 0000-0002-8831-0913 


\section{WAS THERE ANTIQUITIES LAW AND REGULATIONS BEFORE THE ÂSÂR-I ATÎKA NIZÂMNÂME OF 1869?}

\section{9 ÂSÂR-I ATÎKA NIZÂMNÂMESİ ÖNCESINDE ESKİ ESERLER HUKUKU VE KURALLARI BULUNUYOR MUYDU?}

\section{ÖZ}

Bu makale, “Âsâr-1 Atîka Nizâmnâmesi” nin yürürlüğe girdiği 13 Şubat 1869 tarihi öncesi dönemde Osmanlı topraklarında bulunan eski eserlerle ilgili hukuk, idari kurallar ve teamüller konusunu ele almayı amaçlamaktadır. Bu konuda son otuz yıl içinde yayınlanan çağdaş eserlerde defaten 1874 yılında yayımlanan, ya da hatta 1884 yılında yayımlanan Nizamname ile ilgili aynı şey söylense de, 1869 yılı Nizamnamesi'nin sürekli olarak Osmanlı Devletinin tarihi eserleri ile ilgili ilk nizamnamesi olduğu söylenmektedir. Bu çalışmada kullanılan kaynaklar arasında, Osmanlı eski eserlere yönelik uygulamalar ile ilgili daha önce yayınlanmayan Osmanlı arşiv kaynakları bulunmaktadır. 1869 yılı öncesi dönemde eski eserlerin Osmanlı topraklarından ihraç edilmesini yasaklayan ve eski eserler ile ilgili araştırmalara ve antik mahallerde kazı yapmaya kısıtlama getiren idari uygulamalar/düzenlemeler bulunuyordu. Bunlar, Osmanlı topraklarının tamamını kapsıyordu. 1869 Nizamnamesi ise, eski eserlerle ilgili mevcut yasal ve idari uygulamaları açık bir şekilde yazılı hale getirdi. Örneğin, 30 Ağustos 1852 tarihinde, Edhem Paşa yabancılara eski eserlerin satılmasının önlenmesi için özen gösterilmesi gerektiğine dair uyarılmıştı. Aynı zamanda, 4 Mayıs 1865 tarihli bir belgede Osmanlı Devleti’nde tarihi eserlerle ilgili kazı izinlerinde belirli kurallar içerisinde hareket edilmesi gerektiği görülmektedir.

Osmanlı dışı kaynaklardan elde edilen deliller ise, Tanzimat döneminden iki-yüz yıldan fazla bir süre önce, 17. Yüzyılda yürürlükte olan ve kesin bir izin olmadan eski eserlerin ihraç edilmesini yasaklayan Osmanlı kanunları, kuralları ve teamüllerini göstermektedir. 1623 yılında İngiltere Büyükelçisi, o dönemde eski eserlerin Osmanlı topraklarından dışarı çıkarılmasını yasaklayan hem kanunlar he de teamüllerin bulunduğunu ifade etmiştir. Büyükelçi, bu nedenle, Osmanlı topraklarından eski eserlerin çıkarılması için gizlilik ve rüşvete başvurulabileceğini belirtmiştir. 18 ve 19. Yüzyıllarda yapılan yayınlarda da aynı yöntemler önerilmiştir. Bu makale, modern literatürde 1869, 1874 ve 1884 yılı Âsâr-ı Atîka Nizâmnâmesi üzerinde tekrar tekrar yapılan vurgunun, söz konusu nizamnamenin aslında 1869 yılı öncesinde Osmanlı topraklarından çıkarılan, bugün yurtdışında çeşitli müze ve koleksiyonlarda bulunan oldukça büyük miktarda eski eserlerin gizlilik, rüşvet yoluyla izinsiz ve yasadışı olarak çıkarılmasını yasal hale getirmek olduğunu iddia etmektedir.

Anahtar Kelimeler: Osmanlı Eski Eserler Hukuku, İdari Kurallar ve Teamüller, Çalınan Eski Eserler, Gizlilik ve Yolsuzluk.

\section{INTRODUCTION}

It seems important to realise that in fact, in the Ottoman state tradition, administrative rules and law, qānūn and emirnâme, if there was no official permission, the removal of antiquities from Ottoman territory was forbidden, and, that this was of very long standing indeed. It is today usual to read statements concerning the removal of antiquities from Ottoman territory such as that made by Ada Cohen and Steven E. Kangas in 2010, It was not that he was doing anything unlawful, since the first Ottoman antiquities laws only came into effect many years later, during $1869-74,{ }^{1}$ in respect to the activities of Austin Henry Layard in 1845 in the Ottoman territory of Iraq at Nimrud. Or, as by Edhem Elden in 2011, It was in 1869, forty-one years after the capitulation of the Acropolis, that the Ottoman administration first expressed a serious concern for the preservation of the antiquities lying throughout the large territorial expanse of the empire. ${ }^{2}$ However, to imagine that the Ottoman state had no regulations on this matter of the protection of antiquities until the Âsâr-l Atîka Nizâmnâme, Reglement sur les objets antiques, the so-called first law on antiquities came into force on the $13^{\text {th }}$ of February 1869, which banned antiquities from being taken beyond the borders of the Ottoman state unless special permission for their export was obtained $;^{3}$ although on this, some scholars and others, have in error alleged that

\footnotetext{
${ }^{1}$ Editing of this article I have much appreciated the assistance of T. M. P. Duggan of MCRI, Akdeniz University. Ada Cohen, Steven E. Kangas, Assyrian Reliefs from the Palace of Ashurnasirpal II: A Cultural Biography, Hood Museum of Art, Dartmouth College, Hanover, NH., 2010, p.96.

${ }^{2}$ Edhem Eldem, "From Blissful indifference to Anguished Concern: Ottoman Perceptions of Antiquities, 1799-1869," Eds. Z. Bahrani, Zeynep Çelik, Edhem Eldem, Scramble for the Past: A Story of Archaeology in the Ottoman Empire, 1755-1914, SALT/Garanti Kültür A.Ş., Istanbul 2011, p.312-314.

${ }^{3}$ This decree required permission, when requested, to search for antiquities. It allowed free trade in antiquities within the Ottoman territory but prohibited exportation. The finder of antiquities on his land was considered the owner. So, the 1869 decree allowed private ownership over antiquities found within the Ottoman territory - within limits. Sibel Özel, "Under the Turkish Blanket Legislation: The Recovery of Cultural Property Removed from Turkey", International Journal of Legal Information 38/2, 2010, p.178.
} 


\section{CEMIL CELİK}

the first Ottoman antiquities legislation was in $1874,{ }^{4}$ or even later, in 1884 ; is a quite strange notion, given the strength of the Ottoman state tradition over the previous more than four hundred years, particularly when this is combined with the published record of the longstanding removal of antiquities from Ottoman territory legally, that is, with the remover in possession of the necessary firman actually recording the permission given for the removal of antiquities from Ottoman territory. The evident and known corollary to this being that in the absence of the necessary permission in a firman explicitly permitting it, it was the case that antiquities could not be legally be removed from Ottoman territory. That a firman would be issued to a foreigner by the Porte to permit excavation or the removal of antiquities from a place without the relevant officials of the administration also being informed in writing on this matter, as has been stated for example by Wendy M. K. Shaw, If any regulation regarding antiquities existed the only possible mention of it would be in firmans, ${ }^{5}$ in Ottoman administrative terms makes no sense, and is indubitably refuted by the surviving Ottoman archival administrative sources recording regulations concerning antiquities dating from before 1869. If the Ottoman administrative record and the pertinent law qānūn-emirnâme had been read, just perhaps, George Roy Haslam Wright (1924-2014), admittedly no specialist in Islamic/Ottoman law, would not have written, equally nothing is known of any Ottoman qānūn specifically regulating antiquities. If such existed, logically, it might be mentioned in firmans issued to cover antiquities work - and so far as is evident it never was. ${ }^{6}$

\section{Applications for Historical Artefacts in the Ottoman State}

The whole question of which of the numerous official firman issued to individuals for their protection in travelling and at times sightseeing for antiquities from A to B in Ottoman territory, as for example that granted to Dr. Richard Pococke, a document employed with effect in 1740 at Eskihissar-Stratonicea to enable the copying of an inscription, ${ }^{7}$ an official passport - laissez-passer, ${ }^{8}$ at times also explicitly permitted the removal of antiquities, of course requires further investigation from the particular statements made in the documents themselves, not, where possible, from their varied interpretations, misuse, and translations, but it seems evident that unless the search for, and, or the removal of antiquities was explicitly mentioned in the document, it was not permitted, nor was the excavation for them permitted.

For example, permitted, i.e. legal removal abroad was the case in the firman issued $6^{\text {th }}$ July 1801 for ambassador Elgin's removal and export of Sultan Mahmud II.'s gift, of the Parthenon and other sculptures and inscriptions, ${ }^{10}$ and in another, secured by ambassador Robert Adair in Feb. 1810, to finally enable the removal

\footnotetext{
${ }^{4}$ This (the second, 1874) decree adopted for the first time the principle of state ownership of undiscovered antiquities on Ottoman soil. The 1874 decree prohibited excavating for antiquities without the permission from the Ministry of Education and the consent of the landowner, Özel, idem.

5 Polina Nikolaou, "Archeology, Empire and the Field: Exploring the Ancient Sites of Cyprus, 1865-1876", Eds. Diarmid A. Finnegan, Jonathan Jeffrey Wright, Spaces of Global Knowledge: Exhibition, Encounter and Exchange in an Age of Empire, Routledge, London-New York 2016, p.46, fn. 42, citing Wendy M. K. Shaw, Possessors and Possessed: Museums, Archaeology, and the Visualization of History in the Late Ottoman Empire, Berkley: University of California Press, 2003, n.p.n.

${ }^{6}$ G. R. H. Wright, “Archaeology And Islamic Law In Ottoman Cyprus”, Ed. Veronica Tatton-Brown, Cyprus in the 19th Century AD: Fact, Fancy and Fiction: Papers of the 22nd British Museum Classical Colloquium, December 1998, Oxbow Books, 2001, p.263; also, G. R. H. Wright, "The Legality Of The Consular Excavations In Ottoman Cyprus", Ed. Veronica Tatton-Brown, Cyprus in the 19th Century AD: Fact, Fancy and Fiction: Papers of the 22nd British Museum Classical Colloquium, December 1998, Oxbow Books, 2001, p.4, It is unsurprising that this paper was included in this 2001 publication by Veronica Tatton-Brown 1944-2012, former deputy keeper of Greek and Roman antiquities, British Museum and Fellow of the Society of Antiquaries, given the not insignificant legal matter of the ownership of antiquities stolen, as distinct from legally removed, from former Ottoman territory.

${ }^{7}$ Richard Pococke, A Description of the East, and Some Other Countries, Vol. II. Part II., Observations...W. Bowyer, London 1745, p.6465 , but if I would make certain presents to him and his cadi, I might view what I pleased. I gave him to understand, that by virtue of my firman I could see the antiquities, and that he must answer (for) it, if any harm happened to me there. I left him, and pursued my observations as before.

${ }^{8}$ Described by Robert Wood as my Turkish firman or passport, Robert Wood, An Essay on the Original Genius and Writings of Homer: With a Comparative View of the Ancient and Present State of the Troade, T. Payne, P. Elmsly, London 1775, p.153. A yol emri, as distinct from a local travel permit, yol teskeré/tescaree/teskerèy, a document normally required in order to be allowed to make a journey from one Ottoman sandjak into another. It seems probable that rather than a teskeré, a firman was intended by Joseph Thatcher Clarke, Report on the Investigations at Assos, Papers of the Archaeological Institute of America: Classical series, Vol. II., 1882, 1883, Part I. Macmillan Co., New York 1898, p.36, While awaiting a decision in this matter, and the issue of the teskeré which should permit the removal of the antiques belonging to the expedition, all the objects were packed in wooden cases: the inscriptions and smaller stones being wrapped in hay, the vases and figurini in a fine dried seaweed. A teskere was not the type of document that recorded permission for the export of antiquities from Ottoman territory.

${ }^{9}$ That the acquisition of firmans from persons other that the sultan that permitted removal was abused and that firmans were abused in respect to antiquities and their removal seems evident from George Robins Gliddon's remarks: It would then be well, wherever individuals, Societies, or Governments, desire to remove from Egypt any relics of antiquity; or to prosecute researches by excavation, or otherwise, in pursuit of such objects, the power of granting permission to such parties be recognised as an attribute of the Sultan's territorial rights; and that such removal of, or research after, Egyptian antiquities, be forbidden to all, who do not have a special Firman for such purpose, emanated by the Sultan, and by him alone. George Robins Gliddon (Late U.S. consul at Cairo), A Memoir on the Cotton of Egypt, James Madden and Co., London 1841, p.148.

${ }^{10}$ The text of a firman of c. 1801, recorded by the Rev. Mr. Hunt, Chaplain to the British Embassy, and addressed to the Voyvode (Governor) of Athens: That in order to shew their particular respect for the Ambassador of Great Britain, they gave him and his artists the
} most extensive permission to draw, view, and model the antient temples of the idols, and the sculptures upon them, and to make excavations 


\section{WAS THERE ANTIQUITIES LAW AND REGULATIONS BEFORE THE ÂSÂR-I ATÎKA NIZÂMNÂME OF 1869?}

from Ottoman territory of the remainder of the antiquities from Athens and elsewhere collected by ambassador Elgin. A firman was granted in Feb. 1818 by the kakia/kiayah/Kiahaja-Bey, Kavalalı Mehmed Ali Pasha being absent from Cairo, to Giovanni Battista Belzoni to excavate the Giza pyramids, after checking that there was no cultivated land in the vicinity that would be disturbed by this activity; ${ }^{11}$ while another was obtained in 1822 from M. Ali Pasha, by M. Claude de Lorrain, in the employ of M. Sébastien-Louis Saulnier, permitting him to make researches and excavations in certain ancient buildings, the removal of the Dendera zodiac relief to France, ${ }^{12}$ and another granted by M. Ali Pasha in April 1252/1836 to again excavate the Giza pyramids. ${ }^{13}$ The latter is important because the firman was interpreted by the moudir/müdür of Ghize as permitting excavation, but not the removal of antiquities, which was not specified in the firman, indicating the Ottoman state tradition on this matter. ${ }^{14}$ A firman permitting excavation meant exactly that. It did not include the legal removal of any excavated finds unless this was stated in the firman, ${ }^{15}$ the whole matter of exceeding the terms of the firman. Under the pressure of the British consul-general in Egypt 1833-1841, Patrick Campbell's representations to M. Ali Pasha, the müdür of Giza was sacked. A firman was granted by Sultan Mahmut II in 1838 to Désire RaoulRochette for the removal ${ }^{16}$ of antiquities, including one capital and 13 metopes and bas-reliefs from the architrave of the Temple of Assos, the II $^{\text {nd }}$ Century B.C. frieze from the Temple of Artemis Leukophryene at Magnesia ad Meandrum depicting a battle between Greeks and Amazons and the vase from Pergamus, all of which were legally brought from Ottoman territory to the Musée du Louvre, Paris. Another was granted by Sultan Abdülmecid 'in consequence of the sincere friendship existing between the two governments,' for the removal (aided by Charles Fellows) of Lycian antiquities to Britain in $1841,{ }^{17}$ and, in $1846^{18}$ for the removal and

and take away any pieces of stones, with figures or inscriptions, which might be interesting to him. R. Walsh, Account of the Levant Company, London 1825, p.48-49. Or, “...or in excavating when they find it necessary the foundations in search of inscriptions among the rubbish;...nor hinder them from taking away and pieces of stone with inscriptions and figures... "Translation of the Italian copy of this firman by William St. Clair, Lord Elgin and the Marbles, Oxford 1983.

${ }^{11}$ Giovanni Battista Belzoni, Narrative of the Operations and Recent Discoveries Within the Pyramids, Temples, Tombs, and Excavations in Egypt and Nubia;..., H. Remy, Brussels 1835, p.239-240; idem, p.6, He seemed to be pleased when he was told, that I was going to make a collection for myself, for which reason, as he said, he had given me the firman with full power to dig wherever I pleased, right and left of the Nile. Giovanni D'Athanasi, A Brief Account of the Researches and Discoveries in Upper Egypt, Made Under the Direction of Henry Salt: To which is Added a Detailed Catalogue of Mr. Salt's Collection of Egyptian Antiquities...for the British Museum, John Hearne, London 1836, p.18-19; for the firman for the excavation issued after it was known that the land which we were going to dig up had not been reserved for sowing. Idem, p.19. In, Col. Howard Vyse, Operations carried on at the pyramids of Gizeh in 1837,..., Vol. II., James Fraser, London 1840, p.299-300, it is related that this firman was obtained by Signore Athanasi, dragoman to Consul-General Salt (appointed 1815, 1816-1827), but, given the numerous allegations between Belzoni and Athanasi (Yani), both employed at times by Salt, in the absence of the firman itself, in whose name it was actually issued to is today unclear. But it is evident that a firman at times was issued in the name of the foreman-works manager.

${ }^{12}$ The firman for his protection in the search for antiquities in Wadi-Halsa, is in translation, M. Lelorrain, "A Journey in Egypt and Observations of the Circular Zodiac of Denderah by M. Saulnier,” Voyages and Travels: Consisting of Originals and Translations, Vol. VIII. Richard Phillips, London 1822, p.79; re indicated authorisation for their removal, idem, p.87.

${ }^{13}$ The firman was first made out in the name of Howard Vyse and Patrick Campbell, addressed to the Moudir, Governor of the district of Ghize; and then was re-issued in the name of M. Caviglia, see: Col. Howard Vyse, Operations carried on at the pyramids of Gizeh in 1837: with an account of a voyage into Upper Egypt, and an appendix, Vol. II., James Fraser, London 1840, 165; idem, p.164, for the translation of the Ottoman firman into Italian.

${ }^{14}$ The müdür of Giza had added to the instructions given in the firman, in his written instructions for the Sheiks of the district, to keep a strict watch that nothing should be carried off (from the excavations) by Patrick Campbell or Howard Vise. The müdür drawing the, to be expected distinction between the excavation itself, and the removal of any antiquities discovered, idem p.165. As likewise on Cyprus, Cenap Effendi, Larnaca district governor, due to his concerns about illegal excavations, was in 1867 dismissed through consul Cesnola's representations. Cemil Çelik, "The American Consul Cesnola Brothers and the Fate of Antiquities in Ottoman Cyprus" Bingöl Üniversitesi Sosyal Bilimler Enstitüsü Dergisi, 22, 2021, p.272. For an example of the careful reading of a firman, "He read the firman through several times. The document was duly signed and sealed; the wording of this writ of habeas corpus was so precise there was no evading it... "The firman," quoth he, "makes mention of lions aslanlar; but the animals in the walls of the castle are leopards, caplalanlar." Charles Thomas Newton, Travels and Discoveries in the Levant, Vol. II., Day and Son, Ltd., London 1865, p.103.

${ }^{15}$ Likewise indicating the practice of reading a firman in a literal manner, The captain of a French frigate was refused admittance (to Bodrum Castle), until he presented his firman. Then, as he was entering, the foreman 'quietly reminded him that the firman said nothing about his coming out again, so he must remain inside,'so the poor man was as far off as ever from seeing them (the mausoleum reliefs built into the interior walls). Patrick Balfour, Baron Kinross, Europa Minor: Journeys in Coastal Turkey, John Murray, London 1856, p.73. As likewise the American Consul on Cyprus, Luigi Palma di Cesnola, recorded the Governor General of Ottoman Cyprus remarked that: as in my firman it was not specified that I could send them (the finds) away, he could not permit me to transport them out of the island, but had received positive orders to forbid their embarkation... "you have asked for a firman to dig, which has been granted, but not to transport! I asked him what he supposed had been my intention in asking for that firman? That he declared himself unable to say." Luigi Palma di Cesnola, Cyprus: Its Ancient Cities, Tombs, and Temples: A Narrative of Researches and Excavations During Ten Years' Residence as American Consul in that Island, John Murray, London 1877, p.171.

${ }^{16}$ Bonna D. Westcoat, The Temple of Athena at Assos, Oxford University Press, Oxford 2012, p.10-13.

${ }^{17}$ Enid Slatter, Xanthus, Travels of Discovery in Turkey, Rubicon Press, London 1994, p.214, the application for which had been initially rejected in 1840, owing to the 'generality' of the request, idem, p.176-177, in part, as it also included the request for the Bodrum bas-reliefs, idem, p.216; on this see also, Gordon Waterfield, Layard of Nineveh, John Murray, London 1963, p.134-135. The firman for the removal from Lycia was renewed after two years, Slatter, op.cit., p.217. There is an earlier example from 1829 of the rejection of a request for a firman to remove an antiquity. Both the British and the French applied to Kavalalı Mehmed Ali Pasha to remove from a mosque a stone carved with Egyptian hieroglyphs and both applications were rejected by the pasha, but, in ignorance of his father's decision, the French then applied for one from his son İbrahim, who granted it. George Robins Gliddon, Ancient Egypt: Her Monuments, Hieroglyphics, History and 


\section{CEMIL CELİK}

export of the Bodrum castle ${ }^{19}$-Halikarnassos Amazon reliefs, a gift from Sultan Abdülmecid to the British Ambassador Stratford Canning, their removal from the castle walls supervised by an Ottoman military engineer and executed by his Oriental Secretary, Charles Alison, and the crew of R.N. sloop Siren; ${ }^{20}$ and for Henry Layard's excavation and removal of sculptures and inscriptions from Nimrud, ${ }^{21}$ the firman, secured by Stratford Canning from the grand vizier, dated 5 May $1846,{ }^{22}$ long after Layard had begun work at the site on the $9^{\text {th }}$ of November $1845 ;^{23}$ and in 1856 for Charles Newton's excavations at Halikarnassos; another in 1857 permitting the removal of the lion sculptures from the mausoleum in the walls of Bodrum Castle; ${ }^{24}$ another of August 1858, permitting excavation and the removal of antiquities by Charles Newton at Bodrum, obtained by ambassador Sir Henry Bulwer. Another granted by the pasha of Tripoli permitting excavation at Cyrene in 1860-61 by Lieutenant Smith R.E., and Lieutenant Porcher, R.N., and the removal of the finds; ${ }^{25}$ and another issued permitting John Turtle Wood's excavations on behalf of the British Museum at Ephesus from May 1863 onwards, also secured by Sir Henry Bulwer. John Turtle Wood's 1863 firman, renewable after a year, permitted excavation at Ephesus and Colophon and the export of finds, leaving all duplicate finds to the Ottoman government, and the excavator was required to obtain the consent of the owners or occupiers of non-state land, for it to be excavated ${ }^{26}$ this in the period before the implementation in 1869 of the Âsâr-ı Atika Nizâmnâme, which likewise forbade the removal from Ottoman territory of antiquities, except if explicit permission was granted for this removal.

As was required in J. T. Wood's firman, examples of duplicate finds were to be sent to the Müze-i Hümayun, ${ }^{27}$ Imperial Ottoman Museum following the regulation dated the $26^{\text {th }}$ of April $1863 .^{28}$ But it is the case that the matter of duplicates, amongst other archaeological matters, was already being regulated before the regulation of the $26^{\text {th }}$ of April 1863. This is clearly recorded in an emirname, an order from the Grand Vizier to the Governor of Izmir dated $4^{\text {th }}$ April 1863. It reads:

"It was reported from the British Embassy that the British citizen Monsieur Çon Portle Vud (John Turtle Wood) was coming to explore the ruins around the Eski Kale-Old Castle in the vicinity of Ayasuluk Gavur Village in Aydin Province, and he would be there until the beginning of June 1863 and he must be shown the necessary assistance. As it is known, it is the rule for those who do antique researches that one of a pair figures which are unearthed, should be left to the Imperial Museum The other one of the pair and the unique ones can be taken by himself. Permission will not be given for the removal from the place in which

Archceology, and Other Subjects Connected with Hieroglyphical Literature, Wm. Taylor and Co., New York 1847, p.8. A later rejection of an application for a firman in 1889 by the Palestine Exploration Fund, for excavation in Jerusalem and on both sides of the Jordan for the purpose of identifying Bible places was rejected by the Porte in Feb. 1889 because the particular sites needed to be designated before a firman could be granted, John M. Matthers, "Excavations by the Palestine Exploration Fund at Tell El-Hesi 1890-1892", Ed. B. T. DahlbergK. G. O'Connell, S.J., Tell El-Hesi: The Site and the Expedition, Eisenbrauns, Winona Lake, Indiana 1989, p.38. While an official rejection of the implementation of a firman due to its possibly deliberately imprecise wording is also recorded, William John Bankes, who visited Bodrum in 1816, thought the Mausoleum frieze superior to the Elgin Marbles and the Bassae frieze. He had a firman to remove the slabs from the Castle, but it is said to have been 'so vaguely worded that the Pasha who commanded at Boudroume refused to permit the marbles to be removed." Brian F. Cook, Bernard Ashmole, Donald Emrys Strong, Relief Sculpture of the Mausoleum at Halicarnassus, Trustees of the British Museum, Oxford University Press, Oxford 2005, p.5.

${ }^{18}$ Stanley Lane-Poole, The Life of the Right Honourable Stratford Canning: Viscount Stratford de Redcliffe, Vol. II., Longmans, Green and Co., London, New York 1888, p.151, Canning writes, My right of possession was obtained from the Sultan, who has made them a personal gift to me; the de facto possession derives from the studied and determined exertions of a party of people, headed by Mr. Alison, an Oriental savant here, whom I sent down to secure and embark them. The valuables are now on their way to Malta in H.M. ship Siren. They occupy sixteen cases in all, weighing about twenty tons.

${ }^{19}$ Halicarnassus, Halik, Bodroumi, Boudroun, Boudroum, Boudroume, Budroon, Boodroom, Budrum, etc.

${ }^{20}$ Brian F. Cook, Bernard Ashmole, Donald Emrys Strong, Relief Sculpture of the Mausoleum at Halicarnassus, Trustees of the British Museum, Oxford University Press, Oxford 2005, p.6; Newton, op.cit., p.80.

${ }^{21}$ Prior to securing the firman permitting excavation and removal in 1846, ambassador Canning had written in his instructions to Layard in 1845, that Layard was, to do his best to obtain permission on the spot for the removal of objects discovered. Lane-Poole, op.cit., p.138.

${ }^{22}$ Waterfield, op.cit., p.142, l'Ambassade Britannique a prié qu'il ne soit pas mis d'obstacles a ce que le gentilhomme susmentioné prenne des pierres qui peuvent lui sevir, ainsi qui celles qu'il pourra découvrir au moyen des fouilles qu'il fera dans les endroits que l'on croit renfermer des pierres de ce genre, et à ce qu'il les embarque pour faire transporter en Angleterre. British Museum, 22 July 1846 , Sir Stratford Canning has obtained from the Porte a firman or vizierial letter, authorizing him to carry on the excavations (at Nimroud) to any extent, and to remove and export such objects of antiquity as he may desire to possess. Parliamentary Papers, Appendix to Report from the Select Committee on Miscellaneous Expenditure, H.M. Stationery Office, London 1848, p.214. It can be noted that Layard's initial excavations at Nimrud, like those of Paul-Émile Botta from 1842, were undertaken without a firman having been issued. While in 1856, Charles Newton awaiting the arrival of a firman, which, in fact, was never issued, still opened tombs and excavated at Bodrum, Newton, II., op.cit., p.46-67, 100-101.

${ }^{23}$ Waterfield, op.cit., p.132.

${ }^{24}$ Newton, II., op.cit., p.100-105.

${ }^{25}$ William Sandys Wright Vaux, On Recent Excavations at Cyrene by Lieutenant R. M. Smith, R. E., Transactions of the Royal Society of Literature, London 1863, p.6-7.

${ }^{26}$ John Turtle Wood, Discoveries at Ephesus: Including the Site and Remains of the Great Temple, James R. Osgood and Co., Boston 1877, p. 16 .

${ }^{27}$ Devlet-i Aliyye Museum / Müze-i Osmani/ Müze-i Hümayun/ Saltanat-1 Seniye müze, Imperial Museum, all refer to the same institution.

${ }^{28}$ Halil Çal, "Osmanlı Devleti'nde Âsâr-1 Atika Nizâmnâmeleri”, Vakıflar Dergisi, 26, 1997, pp. 391-400, 391; Kamil Su, Osman Hamdi Bey'e Kadar Türk Müzesi, ICOM Türkiye Milli Komitesi Press, Istanbul 1965, p.51. 


\title{
WAS THERE ANTIQUITIES LAW AND REGULATIONS BEFORE THE ÂSÂR-I ATÎKA NIZÂMNÂME OF 1869?
}

\begin{abstract}
they have been set up of those antiquities that have been erected in some location as a symbol (alamet olarak) or that have been placed (i.e. in situ) in any other way. Also, if historical artifacts are to be researched in the areas that do not belong to the Government, it is necessary to obtain permission from the owner of the area. Since the person who is concerned is allowed to export figures from the excavation site until the beginning of June, he should be shown the necessary assistance. If there will be historical artifacts to be given for the Imperial Museum, they should be taken and preserved and the situation must be reported. $" 29$
\end{abstract}

On the matter of duplicates it is noteworthy that in the course of the removal of the Amathus vase by the French from Ottoman Cyprus in 1865, the similar but smaller, adjacent rock-cut vase which was to be taken following the Ottoman regulation on duplicates to the Imperial Museum was smashed. ${ }^{30}$ This is also recorded in the Ottoman documentation dated 11 Safer 1282 (6 July 1865): There was correspondence between the Cyprus French consul, Monsieur Fonet Dömarko (Louis Dumesnil de Maricourt), and the Limassol müdür about the antique vases to be transported to France, together with a statue, in the area called Old Limassol and that one of the vases was to be given to the Imperial Museum. ${ }^{31}$ It was determined under the control of the dispatched officer that one of the vases (that one which was supposed to be delivered to the Imperial Museum) was broken. ${ }^{32}$ It is unclear from the documentation and accounts if the damage to the smaller vase was accidental, or, deliberate, to ease the removal of the larger vase, or to render the French Louvre example unique. However, it is evident from the communication of the Governor of Cyprus, Ziya Pasha, to the Ministry of Foreign Affairs, dated $31^{\mathrm{st}}$ of May, 1862, that duplicates of the objects found of the same type should be given to the Imperial Museum that the matter of duplicate antiquities was of concern before $1863 ;{ }^{33}$ and this concern with duplicate antiquities is shown in a document dated August 10, 1858. It reads: Koton (Charles Newton), the British viceconsular in Rhodes, is allowed to dig and unearth antiques in Bodrum. Unique antiquities are to be given to him to be exported, and if there are pairs or more than one of the same figure, these antiquities are to be divided, one to the Imperial Museum and the rest to him. Of the earlier antiquities that have been unearthed before, where there were more than one of the same figure and that has not been exported, one of these will be taken for the Museum. ${ }^{34}$ As later in a document dated, December 1, 1860 it reads: During the archaeological excavation in the Limpos Mountain (Mt. Olympus) in Tirhala (from 1881 in the Greek State), British Monsieur Alyot (Mr. Elliot?) will be assisted by the local administration and one of the pair figures which are unearthed, should be left to the Imperial Museum. The other of the pairs and the unique ones can be taken by him. ${ }^{35}$

That official permission was certainly required to export antiquities from Ottoman territory at a much earlier date is clearly indicated in the $17^{\text {th }}$ century, when the English Ambassador 1621-1628, Thomas Roe records in May 1623, if we ask leave, it cannot be obtained, ${ }^{36}$ i.e. that at this time a firman granting permission for the removal of antiquities could not be obtained from the Porte by the English ambassador, and therefore that the recorded removals undertaken of antiquities from Ottoman territory were theft. ${ }^{37}$ It is evident therefore that

\footnotetext{
${ }^{29}$ BOA. HR. MKT. 483/58, as likewise the related published document, also dated 4th April 1863, BOA. İ. ŞD. 11/547 (4.) Eldem, op.cit., p.315-316. It is worth noting that this is a standard form of administrative expression in addressing this matter of antiquities, as occurs earlier in Ottoman official documents e.g. BOA.,HR. MKT., 401/24,

30 "Vase de Amathonte au Louvre:- De Mes Latrie In "l'ile de Chypre" says that the two vases of Amathus were cut out of the rock and the one carried to Paris was detached from its base for the purpose of transport. At the present day there are no traces of the remains of the second vase which were left behind by the French explorers of 1866. An account of the proceedings of Lieut. Eugène Magen who carried off the vase now in the Louvre appeared in the Journal of the Societi d'Agen in 1867." George Jeffery, A description of the Historic Monuments of Cyprus. Studies in the Archaeology and Architecture of the Island, Dalcassian Publishing Company, Nicosia, Cyprus 1918, p.356. It seems the second vase may have been deliberately smashed to facilitate the removal of the larger one. On this see, Thomas Kiely-Robert S. Merrillees, "The archaeological Interests of Samuel Brown, Government Engineer, and his circle of Acquaintances in Late $19^{\text {th }}$ Century Cyprus", Cahier du Centre d'Études Chypriotes, 42, 2012, p.249, fn 24. Gen. L. de Cesnola related in 1877 that, "Fragments of another similar vase still exist, and are lying a few feet from the spot where the other was for many centuries standing, and in view of every passerby." " "The Cesnola Collection", Harper's Weekly, Vol. XXI, No. 1046, Supplement, Jan. 13, New York 1877, p.38-39, where the error that possession of the Amathus vase was taken by comte Charles Jean Mechloir de Vogüe in 1862, is repeated, when it came into French from Ottoman possession in 1865.

${ }^{31}$ Devlet-i Aliyye Museum / Müze-i Osmani/ Müze-i Hümayun/ Saltanat-1 Seniye müze, Imperial Museum, all refer to the same institution.

${ }^{32}$ BOA. VGG d. $386,577 / 1$.

${ }^{33}$ BOA. HR. MKT. 401/24.

${ }^{34}$ BOA. HR. MKT. 250/60

${ }^{35}$ BOA. HR. MKT. 358/34.

${ }^{36}$ T. M. P. Duggan, "On Early Antiquarians in Asia Minor to the Start of the 19th Century", Gephyra, 17, 2019, p.126, 128-130. Sir Thomas Roe, English Ambassador to the Porte 1621-1628, in a letter to the Earl of Arundel of May 1623, "On (the) Asia side, about Troy, Zizicum, and all the way to Aleppo, are innumerable pillars, statues, and tombstones of marble, with inscriptions in Greek; these may be fetched at charge and secretly; but if we ask leave, it cannot be obtained; therefore Mr. Markham will use discretion, rather than power, and so the Turks will bring." Thomas Roe, The Negociations of Thomas Roe in his Embassy to the Ottoman Porte from the year. 1621-28 inclusive, Now First Publ. from the Originals, Society for the Promotion of Learning, London 1740, p.154. The word discretion, in this case, being a euphemism for bribes.

${ }^{37}$ Theft is mentioned at times in travellers' accounts, in respect to the removal of marbles, as by John Morritt in Athens, Over almost every door is an antique statue or basso-rilievo, more or less good though all much broken, so that you are in a perfect gallery of marbles in these lands. Some we steal, some we buy, and our court is much adorned with them, Ed. G. E. Marindin, The Letters of John B. S. Morritt of
} 


\section{CEMIL CELİK}

the obtaining of a firman permitting the legal removal of antiquities from Ottoman territory was known to be essential in the $17^{\text {th }}$ century, as it was in the $18^{\text {th }}$ century, as it was in $19^{\text {th }}$ century prior to 1869 , to make this removal, authorized and legal, rather than a matter of theft and smuggling, and with death as the possible penalty for Ottoman subjects if it was discovered that he had permitted any relics to be removed without the permission of the sultan. ${ }^{38}$ As Edward Daniel Clarke pointed out in his 1801 removal of the colossal statue termed Ceres from Eleusis, The difficulties to be encountered were not trivial. It was first necessary to purchase the statue from the waiwode, or Governor of Athens, who alone had the power to dispose of it. A Firman was then obtained for its removal; the attendance of a Turkish Officer to enforce the order; and a vessel capable of carrying it away. ${ }^{39}$ Likewise, One of the inhabitants (of Bayramitch, Behram, by the Dardanelles) told us he had lately brought thence several broken pieces of sculpture, to which we should be welcome, if we could obtain permission from the Pasha for their removal. This was granted, and we afterwards brought them to England. ${ }^{40} \mathrm{~A}$ key part in the removal of antiquities was obtaining the necessary firman enabling legal removal after duty was paid. The problems caused by the intention of loading 80 cases of antiquities aboard a vessel to leave Ottoman territory, without actually being in possession of a firman permitting this removal, are made quite clear in a letter from Robert Adair in Pera, to the Rt. Hon., George Canning, dated Sept, $25^{\text {th }} 1809$ :

"Sir, on receiving your despatch respecting the antiquities collected by Lord Elgin in the Levant, I did not fail to renew the application which I had already made privately to the Ottoman Government for permission to embark them at Athens. The preliminary steps towards their embarkation not having been taken under the sanction of a firman, I have met with much difficulty in forwarding his Lordship's wishes, and even now it is very doubtful whether the object would be effected so certainly through a firman as through a private application to the Vaivode of Athens. Measures to this effect are now taking by his Lordship's agents in this country, assisted by all the support which I can give them in concert privately with the Reis Efendi, I have the honour to be, etc. ${ }^{, 41}$

It is the case that among many other examples, the Aegina Aphaia marbles were illegally excavated and smuggled out of Ottoman territory, ${ }^{42}$ stolen property, antiquities removed from Ottoman territory illegally through theft, that is, without being in possession of the necessary Ottoman firman authorizing the excavation and for the removal of antiquities in 1811 from Ottoman territory. In the case of the Bassae-Phigaleian Temple relief sculptures, Veli Pasha of the Morea was bribed, induced for $£ 300$ and a gold watch, to issue a firman authorizing the digging and the removal of the finds, ${ }^{43}$ but, following the Porte's removal of the Pasha from office, the excavated temple relief sculptures had to be rapidly smuggled out of the Morea in 1812 via the port of Bouzi to the British-held island of Zante, for fear the Turks shall claim them. ${ }^{44}$ Likewise the Venus de Milo was removed from Ottoman territory without official permission in 1820 by the French.

Yet, the notion that there was no Ottoman restraint upon the removal from Ottoman territory of antiquities, that the Ottomans did not care about the antiquities spread above and below ground throughout Ottoman territory, including visible markers within the landscape, that they were not concerned by their removal from Ottoman territory, that they were indifferent to antiquities until some point in the second half of the $19^{\text {th }}$ century, has become a modern much repeated, and a most 'convenient' error, that serves, doubtless unintentionally, to legitimize the earlier removal of antiquities ${ }^{45}$. A most convenient error, economical with the truth, and thereby removing the stain of illegality, of theft and smuggling, from those many thousands of antiquities in museums and collections today, exhibited and in storage, that were illegally removed, that is removed from Ottoman territory without the remover being in possession of a decree-firman from the sultan - grand vizier or high official, of an imperial Irade of written record permitting the removal, in the period prior to 1869, or, as has been misleadingly stated 1874, or, 1884, dates alleged for the so-called first Ottoman antiquities law. In effect, the most considerable emphasis in numerous publications concerning archaeology, international law and cultural heritage, particularly over the past more than 30 years that has been given to the Âsâr-l Atîka Nizâmnâme of

Rokeby Descriptive of Journeys in Europe and Asia Minor in the Years 1794-1796, John Murray, London 1914, 179, but not theft in respect to removal from the territory of the Ottoman state,

${ }^{38}$ C. P. Bracken, Antiquities Acquired, David \& Charles, London 1975, p.17.

${ }^{39}$ Testimonies of Different Authors Respecting the Colossal Statue of Ceres: Placed in the Vestibule of the Public Library at Cambridge, July the First, 1803; with a Short Account of Its Removal from Eleusis, November 22, 1801, Printed by Francis Hodson, Cambridge 1803 , p.21.

${ }^{40}$ Edward Daniel Clarke, Travels in Various Countries of Europe, Asia, and Africa, Part the Second, Greece, Egypt and the Holy Land, T. Cadell and W. Davies, London 1817, p.162.

${ }^{41}$ Sir Robert Adair, The Negotiations for the Peace of the Dardanelles: In 1808-9: with Dispatches and Official Documents, Vol. I., Longman, Brown, Green and Longman, London 1845, p.272. For the Ottoman documentation on this see Eldem, op.cit., p.292-295, but this letter casts a quite different light upon the subject.

${ }^{42}$ Bracken, op.cit., p.126. Not, at the behest of King Luwig of Bavaria, as has been alleged, Johnathan M. Hall, Artifact and Artifice: Classical Archaeology and the Ancient Historian, University of Chicago Press, Chicago and London 2014, p.6.

${ }^{43}$ Bracken, op.cit., p.143.

${ }^{44}$ Bracken, op.cit., p. 125

45 "The premise of Ottoman indifference served as justification for the removal of objects, even entire monuments, from Ottoman territory to western and central European collections", Benjamin Anderson, "An alternative discourse": Local interpreters of antiquities in the Ottoman Empire", Journal of Field Archaeology, 40/4, 2015, p.450. 


\section{WAS THERE ANTIQUITIES LAW AND REGULATIONS BEFORE THE ÂSÂR-I ATÎKA NIZÂMNÂME OF 1869?}

1869, and to subsequent Ottoman legislation on this matter of 1874, 1884 and later noted above, has 'usefully' served as a screen, to remove from discussion and distance from possible legal action, in effect, to launderlegitimize the illegal removal of large quantities of antiquities from Ottoman territory in the period prior to 1869 , or $1874,{ }^{46}$ since the first Ottoman antiquities laws only came into effect many years later, during 1869-74, or prior to 1884 .

The emphasis on the antiquities law of this period, also, of course, suggests to people unaware of the historical precedent and context of the 1869 legislation, ${ }^{47}$ that the preservation of cultural heritage in Ottoman territory was only a concern of the later $19^{\text {th }}$ century, Tanzimat period under western tutelage, implying thereby that earlier Ottoman sultans and officials were disinterested in the antiquities in Ottoman territory, ${ }^{48}$ supporting a useful longstanding Christian European view of the Muslim Ottoman "Other" as barbarian, ${ }^{49}$ as distinct from the Ottoman of the Tanzimat period, understood to possess a quantity of acquired western culture. ${ }^{50}$ It can be noted that the law on the protection of antiquities in Ottoman Egypt, the "(khedival) decree," of M. Ali Pasha of 1835 that prohibited the export of archaeological treasures without a permit, ${ }^{51}$ like that of Greece of May 1834 , were in ${ }^{46}$ For example, Nancy Serwint, "Review: Cyprus in the 19th Century AD: Fact, Fancy and Fiction: Papers of the 22nd British Museum
Classical Colloquium, December 1998 by Veronica Tatton-Brown", Bulletin of the American Schools of Oriental Research, No. 337 (Feb.,
2005), p.111, quoting from the chapter G. R. H. Wright, Archaeology And Islamic Law In Ottoman Cyprus, Thus prior to 1874, when the
Ottoman Law on Antiquities was created, there was no secular state regulations concerning antiquities, archaeological remains or
excavation activities. Consequently the excavations made by Cesnola (and others) were not illegal on the island. The 1869 clauses include:
and prohibits the export to foreign countries of any antiquities (ancient coins excepted) found in the course of such excavations; Permission
officially applied for in any case by a foreign power can only be granted by special imperial irade, yet, Christina Luke interestingly writes, A
March (sic.) 1869 law allowed for export permission pending diplomatic correspondence between the Sultan and the respective state. C.
Luke, A Pearl in Peril: Heritage and Diplomacy in Turkey, Oxford University Press, Oxford 2019, p.65; Some examples of countries that
promulgated legislation outlawing the export of antiquities are: Turkey in 1874 and then again in 1884... Margarita Diaz-Andreu, "From
Nineteenth-Century New Imperialism to Twentieth-Century Decolonization", Eds., Bonnie Effros, Guolong Lai, Unmasking Ideology in
Imperial and Colonial Archaeology: Vocabulary, Symbols, and Legacy, University of California, Los Angeles 2018, p.10, etc.
47 At times accurately described as a formalizing of (already existing) procedure, e.g., In March (sic) 1869, the Turkish sultan passed an
order that required a permit to conduct excavations, formalising the procedure more than a firman had previously. Joshua R. Trampier,
Landscape Archaeology of the Western Nile Delta, Lockwood Press, Atlanta, Georgia 2014, p.17.

${ }^{48}$ As for example, Emma M. Payne, Casting the Parthenon Sculptures from the Eighteenth Century to the Digital Age, Bloomsbury, London, New York 2021, p.46, Ottoman indifference to antiquities; Blake, op. cit, p.438, fn. 3, Lord Elgin was able to take advantage of this general lack of interest in antiquities when he was granted a firman (a decree issued by the Ottoman Sultan or one of his high officials) allowing the removal of the Parthenon frieze in 1799 (sic. 1801) and its subsequent transportation to the British Museum (sic. to Burlington House, London). Reprinted unchanged, Janet Blake, International Cultural Heritage Laws, Oxford University Press, Oxford 2015, p.2, fn. 15. As likewise, Erdem, op. cit, "Blissful indifference..."; L. Rosenstein, Antiques: the History of an Idea, Cornell University Press, New York 2009, p.94, "Since Ottoman rulers were generally indifferent to antiquities of any kind, the conditions for the future purchase of such antiquities as the Elgin Marbles from the Parthenon were established by good precedent." But, firstly, the Elgin Marbles were not purchased, they were given to the British Ambassador in appreciation of British support against the French occupation of Ottoman Egypt. Other antiquities that had been purchased by the ambassador's agent in Athens were also cased up and exported with those from the acropolis. Consequently, the removal included both those gifted by the sultan and those purchased by the ambassador. Secondly there is simply no evidence presented to support the allegation that Ottoman rulers were generally indifferent to antiquities of any kind. For examples of the talismanic properties attributed by Ottomans and other rulers to ancient sculptures, Hittite, Greco-Roman etc., and for their re-use for public display in Ottoman state structures from the $15^{\text {th }}$ c. onwards, Duggan, op. cit, p.115-167, 132-141.

${ }^{49}$ Giovanni Paolo Marana, The Eight Volumes of Letters Writ by a Turkish Spy, who Liv'd Five and Forty Years Undiscover'd at Paris: Giving an Impartial Account to the Divan at Constantinople of the Most Remarkable Transactions of Europe: and Discovering Several Intrigues and Secrets of the Christian Courts, (especially of that of France) Continued from the Year 1637, to the Year 1682, Vol. IV., G. Strahan, London, 1718, p.100, For the Franks esteem all the Followers of the Prophet, who could neither write nor read, as Barbarians. Abbé Raynal (Guillaume-Thomas-François), A Philosophical and Political History of the Settlements and Trade of the Europeans in the East and West Indies, Trans. J. O. Justamond, Vol. VIII., W. Strahan \& T. Cadell, London 1783, p.24, Ottoman became the chief among these barbarians, as a savage distinguished by his bravery becomes a chief among his equals; for the Turks at that time were only a hord (e) fixed in the neighbourhood of a people who were half civilized. 'Turks and Russians,' p.394-399, for The English Review, Or, An Abstract of English and Foreign Affairs, Nov. London 1787, p.349, Othman, the bravest of all the emirs, who led these ferocious barbarians, having seized Bithynia, became the founder of the Ottoman empire,... Edward Gibbon, The History of the Decline and Fall of the Roman Empire, Vol. XII., A. Strahan, London 1790, p.202, and he upbraids the pusillanimity of the nations, who had tamely yielded to an handful of Barbarians. Rev. T. S. Hughes, "An Address To the People of England in the Cause of the Greeks occasioned by The Late Inhuman Massacres in the Isle of Scio, etc.", The Pampleteer; Dedicated to Both Houses of Parliament, Vol. XXI., London 1822, p.183, Reader, to this happy Isle, adorned by the lavish hand of nature, blessed with peculiar privileges, free from the very presence of Ottoman barbarians,... William Rae Wilson, Travels in the Holy Land, Egypt, \&c. \&c., Vol. II., Longman, Rees, Orme, Brown, and Green, London 1831, p.197, Most devoutly is it to be wished that the Ottoman barbarians, who are, in the strictest sense of the word, a disgrace to the human race, were altogether rooted out. Rev. Isaac Barrow, A Treatise of the Pope's Supremacy, Swords, Stanford, and Co., New York 1834, p.xiii, until at length the imperial seat of the eastern Casars, usurped by Ottoman barbarians, came full into view. Noel Malcolm, Useful Enemies: Islam and The Ottoman Empire in Western Political Thought, 1450-1750, Oxford University Press, Oxford 2019, p.19, It became common practice to refer to all Muslim peoples as barbarians, regardless of their particular cultural characteristics. Closely linked to the characterization of the Ottoman Turks as 'barbarians' was a Renaissance debate about their historical and ethnic origins.

${ }_{50}^{5}$ Austin Henry Layard wrote in 1844 , It is thus with the Turks; they are scarcely Asiatics and have just acquired enough of the European character to destroy many of their virtues and to remove many of their vices. It is this change which is taking place and the uncertainty of its result which renders this country really interesting. Gordon Waterfield, Layard of Nineveh, John Murray, London 1961, p.109.

${ }^{51}$ Foreigners are destroying ancient edifices, extracting stones and other worked objects and exporting them to foreign countries. If this continues, it is clear that soon no more ancient monuments will remain in Egypt. Jason Thompson, Wonderful Things: A History of Egyptology, Vol. II., Oxford University Press, Oxford 2015, p.220. 


\section{CEMIL CELİK}

part, simply the codification of the longstanding Ottoman state rules-regulations forbidding the excavation and also the removal of antiquities from Ottoman territory, without obtaining a decree permitting their removal, as likewise, in forbidding excavations in search of antiquities without official permission.

\section{Some Ottoman $19^{\text {th }}$ Century Archival Evidence Of Ottoman Administrative Rules Concerning Antiquities From Before 1869}

The French orientalist Louis Félicien Joseph Caignart de Saulcy came to Cyprus in 1850 on his way to Jerusalem, toured the ancient remains, and bought and discovered antiquities which he was later to donate to the Louvre. That which caused him to become known in the archaeology of Cyprus was his purchase of a famous electron and silver coated vase in Larnaca. ${ }^{52}$ This damaged Phoenician electrum and silver artefact today in the Louvre, Département des antiquités orientales, dated to the $8^{\text {th }}-7^{\text {th }}$ centuries B.C., is said to have been discovered by villagers on the Acropolis of Idalion (Dali), and, is said to have been bought au poids d'or - for its weight in gold, but probably meaning bought for a large amount, in the bazaar in Larnaca by Theodore Goēpp, the French consul in Larnaca from 1845 to $1848 .^{53}$ This find was bought from him by Louis Félicien de Saulcy who then presented it to the Louvre in $1851 .{ }^{54}$

Ottoman archival documents shows that the Sultan Abdülmecid was himself concerned about the finding and the matter of the illegal removal of this antiquity from Ottoman Cyprus and he ordered an impartial investigation into how this illegality had occurred, clearly recording the sultan's interest in this matter, the measures taken to determine those responsible and to address this matter of the antiquities on Cyprus and their smuggling abroad, of their removal without official permission.

Addressed to the district governorship of Cyprus (undated, but which most probably dates from the end of May, 1852):

An Assyrian tray with some strange gold gilded depictions from around Larnaca in Cyprus was brought to France by a traveller named Monsieur Dösus (M. Louis Felicien Saulcy). When the sultan became aware of this ${ }^{55}$, exact information about the subject was requested by the sultan. How was this historical artefact found and taken away (from Ottoman Cyprus). It was requested by the Sultan that this be investigated and a report on the incident made in an impartial manner. ${ }^{56}$

The reply from the district governor of Cyprus was given on the $19^{\text {th }}$ of Ramadan 1268 (7 July 1852): ${ }^{57}$

"It was taken to France by Monsieur Dosulus (M. Louis Felicien Saulcy), who found a Syriac tray made of simden around Larnaca, with gilding and some strange depictions on it. In May-June 1852 by the Sultan's decree ordering the finding of those responsible for the removal of this antiquity arrived. News of the fate of the tray, which is a historical artefact, was enquired into from the (müdür) administrator of the town of Tuzla, also called Larnaca, as well as from people who knew about this issue. The tray, a historical artefact, was discovered in December 1846 in the field of one of the people of Dali village of Değirmenlik during the administration of Hasan Pasha, (Hasan Pasha arrived on the $4^{\text {th }}$ of March $1846,{ }^{58}$ and his term of duty on Cyprus ended on the $8^{\text {th }}$ of September $1847^{59}$ and was deceased by 1852, placing blame for this loss on the deceased). This tray was not made of gold and silver, but of a kind of ore in the form of a rectangular plates, and it was seen that it was written in Syriac, and it was not known which mine it was from. However, 4 metal cups and 20 kiyye (1kiyye: $1.283 \mathrm{gr}$ ) of bronze rods were found. The owner of the field sold all these at a low price secretly in the town of Tuzla, the tray alone was sold to the French consular interpreter for 140 kurush. The interpreter said he sold the tray to his consul (Theodore Goēpp 1845-1848) who gave it as a present to a man named Dosulus (M. Louis Felicien Saulcy), who had come to the island at the time of the consul $^{60}$. That person took the tray to France. At the time when Hafiz Pasha (kaymakam ${ }^{61}$, from June $1850^{62}$

\footnotetext{
52 The date of 1850 is recorded by Stanley Casson, Cypre dans l'antiquite, Payot, Paris, 1939, p.16, and it is certain. However the date given in the Ottoman document for the stated date of this find of December 1846, would mean that the French consul had kept the find from Dec.Jan. 1847 until 1850 when he sold it to M. Louis Felicien Saulcy which seems most improbable. It seems most probable that the find was actually made in December 1849 and the consul both purchased and sold it in 1850 . The reason for backdating the event to the governorship of Hasan Pasha was that he was, by the time of the investigation required by the Sultan, deceased.

${ }^{53}$ Louvre AO $20135=$ AO $5974=$ N 3454. On this see, Robert Stuart Merrillees, Studies on the Provenances of the Stele of Sargon II From Larnaca (Kition) and the Two So-Called Dhali (Idalion) Silver Bowls in the Louvre", Cahiers du Centre d'Etudes Chypriotes, 46, 2016, p.372.

${ }^{54}$ https://collections.louvre.fr/ark:/53355/c1010171082 where Dali is the suggested findspot.

${ }_{55}$ Presumably from the French or Constantinople press reports of this.

${ }^{56}$ BOA. A.\} MKT. UM. 290/30.

${ }^{57}$ BOA İ. DH. 257/15845, see below annex-1.

${ }^{58}$ BOA. A. MKT. 39/46.

${ }^{59}$ BOA. A.\} TŞF. 3/63; MAA. KŞS.41, 116/1.

${ }^{60}$ In fact, the consul did not give it to M. Louis Felicien Saulcy, the consul sold it to him.

${ }^{61}$ Kymacèhm, Kaimachan, caimakam, etc.

${ }^{62}$ BOA. A.\} MKT. MVL. 28/70.
} 


\section{WAS THERE ANTIQUITIES LAW AND REGULATIONS BEFORE THE ÂSÂR-I ATÎKA NIZÂMNÂME OF 1869?}

to November $1851^{63}$ ), had just begun his mission, he (the French consular interpreter) was again served by the Dali villagers with 50 dirhams each $(1$ dirhams= 3.2 gr.) of 14 pieces of scrap silver bowls which were found and sold to a jeweller in Tuzla for a kurush for each dirham. It was reported at the time of Hafiz Pasha that the jeweller in Tuzla melted them down because these were scrap silver in the jewellery store ${ }^{64}$. It was related by the villages and the administrator that one of these found by the villagers of Tuzla and Dali was in a good condition and given by the (consular) interpreter to an official of the French consul in Beirut".

Although, "one of these found by the villagers of Tuzla and Dali in a good condition" could be mistaken for the famous bronze tablet, said to have been found by villagers at Dali (Dalium-Idalie, Idalium), the Dali Tablet which was purchased from M. Aimé Peretié, chancellor of the French consulate in Beirut, by Honoré Théodoric d'Albert, Duc de Luynes in 1850, all the 14 pieces are described as being of scrap silver rather than of bronze. But this document does confirm a route that was employed at this time for the removal of antiquities from Cyprus, via the French consular interpreter on Cyprus to the French Beirut consulate.

The sultan's comments concerning this reply were written to Edhem Paşa on the $30^{\text {th }}$ of August, 1852:

The Governor of Cyprus, Edhem Paşa, was warned that care should be taken to prevent the selling of these ancient pieces to the foreigners. And the people of this area of Cyprus were warned and asked to inform the island administrators immediately (antiquities were found). ${ }^{65}$

In the document sent by the Governor of Cyprus, Ziya Pasha, to the Ministry of Foreign Affairs, dated $31^{\mathrm{st}}$ of May, 1862; The Governor of Cyprus stated that some foreigners misuse the permit and the conditional permits they obtained for research on the historical artefacts of the island, and then they excavate in the regions as they want and they take these artefacts to their own country secretly in private ships without informing the local administration. According to the order; duplicates of the objects found of the same type should be given to Imperial Museum, and the local antiquity markers, ${ }^{66}$ indicating some artifacts and meanings (above ground) should not be touched ${ }^{67}$. In addition, excavations were being carried out without the permission of the land owner, but excavation on non-state land required the permission of the landowner. Since the district managers are asked to act according to the instructions expressing how to implement the issue, the problems experienced by them during implementation (the infringement of these) are constantly complained of by the müdürs to the Cyprus Governor. Although there are many historical artifacts on the island and are very valuable, it is certain that there will be no historical artifacts left on the island to be found, if the historical artifacts taken from the island continue to be removed (at the current rate). ${ }^{68}$ For this reason, if excavations of historical artifacts are completely prevented, much benefit will be provided to the state and the country. At least, it will be in the interest of the state to more narrowly delimit the borders and the rules in the permissions issued for excavation ${ }^{69}$.

\subsection{The Necessary Rules, And The Necessary Compliance (with) The Procedure}

Westerners who wanted to search for ancient artifacts in the Ottoman territory had to get permission from the Sublime Porte before the Regulation of 1869. In a document dated 11 C. Evvel 1281 (October 12, 1864) clearly shows this application:

It is understood that Abito, a French citizen on Cyprus, is to look for antiquities in some parts of the island. Permission was requested by the French embassy for him to search for antiquities in Cyprus. The issue was discussed in the Meclis-i Vâlâ-yı Ahkâm-ı Adliyye, (the supreme council of judicial ordinances). In accordance with the decision taken, it was decided to give permission, provided that his expenses are his, and that he did not demand anything for this in the future, and that he obeyed the necessary rules.

The related document dated 25 C. Evvel 1281- October 26, 1864, states:

\footnotetext{
${ }^{63}$ BOA., A. \} A.\}TŞF. 10/66.

${ }^{64}$ Similarly, later at Troy in 1873, Unfortunately one of the workmen had got his part of the booty (of March 1873) melted down by a goldsmith at Ren Kioi, and made into ornaments after the present Turkish fashion, Heinrich Schliemann, Ilios: The City and Country of the Trojans: the Results of Researches and Discoveries on the Site of Troy and Throughout the Troad in the Years 1871-72-73-78-79: Including an Autobiography of the Author, John Murray, London 1880, p.43.

${ }^{65}$ BOA İ. DH. 257/15845, response to BOA. A.\} MKT. UM. 290/30.

${ }^{66}$ The word, alamet, is here translated as marker, it could also possibly be understood to mean tilsim- a talisman.

${ }^{67}$ Markers in the landscape, such as a solitary standing ancient column, or monumental vase, these should be left alone, should not be removed; as is later recorded, 4 May 1865, in addition, it is the rule that the state has applied for a long time, to leave unique historical artefacts alone. In a region, it is not allowed to remove a historical artefact, which is very large and standing upright when compared to its counterparts or placed in a different way, from the place where it was erected.

${ }^{68}$ This passage closely resembles that of M. Ali Pasha's Khedival decree of 1835 , op. cit. fn. 48.

${ }^{69}$ BOA. HR. MKT. 401/24, see below annex-2.
} 
The Frenchman Abota, heard that there were some antiquities in Cyprus and asked for permission to search for them. It was decided to allow him to conduct research where necessary, provided that the new procedure was followed. $^{70}$

Likewise in the special permission for the removal of the Amathus Vase that had been given by order of Sultan Abdulaziz in May 1865, so that the French subjects appointed by the French Emperor Napoleon III. who was interested in antiquities, could remove antiquities from the district of Tuzla in $1865,{ }^{71}$ the document reads:

In the order dated 8 Zilhicce 1281 (4 May 1865) written to the Governorship of Cyprus

In the written request of the French Embassy, a person named Dütua (Edmund Duthoit), one of the subjects of the French state, went to Cyprus to search for historical artefacts in Cyprus. Dütua was asked to show the necessary compliance. For those who search for historical artefacts, any duplicates of historical artefacts found are to be released to the Imperial Museum. In addition, it is the rule that the state has applied for a long time (kaide-i miriye), to leave unique historical artefacts (above ground) alone. In a region, it is not allowed to remove a historical artefact, which is very large and standing upright when compared to its counterparts or placed in a different way, from the place where it was erected. When searching in non-state areas, the consent of the owner of that place is required. In accordance with these conditions, the said consul asked to be allowed to research historical artefacts and to show the necessary compliance. ${ }^{72}$

The expressions in bold above, that he obeyed the necessary rules, and, provided that the new procedure (in respect to antiquities) was followed, show the necessary compliance (with the rules), all implicitly record there were both rules and old Ottoman, and, new in 1864, procedures, presumably in respect to duplicate antiquities, regulations that were already in effect in Ottoman territory. Further, the document of the $4^{\text {th }}$ of May 1865 is explicit on the matter of the longstanding Ottoman rules regarding antiquities, In addition, it is the rule that the state has applied for a long time, to leave unique historical artefacts alone.

\subsection{Since It Is A Rule That The Historical Artefacts That Are Taken Out Of The Island With Official Permission Should Be Given to Their Owners, It Is The Rule That The Stone Should Not Be Shipped}

There were a series of incidents with French citizens in the Tuzla Customs-House in 1863, the subject of a forthcoming article, and the following is the translation of a text sent from the French Embassy to the Ministry of Foreign Affairs on the $20^{\text {th }}$ of August, 1865, which reads:

"In 1862, Monsieur Renan and Monsieur Lokonet Dovevki (comte Charles Jean Mechloir de Vogüé), who were assigned to research historical artefacts, found stones with depictions in the area called Iteno near Tuzla. The stones with depictions were placed in a chest. Since they were going to France, they had asked some people to send this chest to France. However, this chest has remained in Tuzla customs ever since. Permission to investigate was given to Monsieur Dötova (Edmond Duthoit), who was re-appointed by France. The chest was asked to be taken from the customs and taken out of the island. However, the chest remained in the customs to be given to someone else possessing the decree of the sultan. Upon these developments, it was declared by the administration of the Rüsumat (Customs and Excise) that the chest could not be released unless a special order came from Istanbul himself (i.e. from the sultan-porte). Therefore, the Embassy of France requested the Tuzla Rüsumat officials not to cause difficulties for Dötova (Edmond Duthoit)". 73

To the Cypriot governorship and the Trust of Rüsumat, dated, 13 R. Ahir 1282 (5 September 1865)

An ancient stone with depictions unearthed by a French subject was left behind by Monsieur Renan who was commissioned to research antiquities in Cyprus. Instead of Renan, the historical artefact was taken to the Cyprus customs by Dötova, who was in charge of historical artefact research, with the request that it be transferred to France. The shipment was kept here. Since it is a rule that the historical artefacts that are taken out of the island with official permission should be given to their owners, it is the rule that the stone should not be shipped. ${ }^{74}$

These two documents of 1865 likewise indicate the existence of established state practice concerning the legal removal of historical artefacts from Ottoman territory. They clearly record in the years prior to the implementation of the "Âsâr-1 Atîka Nizâmnâmesi" in 1869 that to legally remove antiquities from Ottoman

\footnotetext{
${ }^{70}$ BOA. MVL. 794/57.

${ }^{71}$ Mesut Ayar, "XIX. Yüzyılın İkinci Yarısında Tuzla (Larnaka): Ticaret, Ticaret Mahkemesi ve Konsolosluklar", Histories of Ottoman Larnaca, Eds. Evangelia Balta-Theoharis Stavrides-Ioanis Theocharides, The Isis Press, Istanbul 2012, p. 354.

${ }^{72}$ BOA. HR. MKT. 532/40, 6; BOA. BEO. VGG. D., 386, p. 129, no.84.

${ }^{73}$ BOA. HR. MKT. 525/47.

${ }^{74}$ BOA. HR. MKT. 525/47.
} 


\section{WAS THERE ANTIQUITIES LAW AND REGULATIONS BEFORE THE ÂSÂR-I ATÎKA NIZÂMNÂME OF 1869?}

territory required possessing the decree of the sultan. Without the owner in possession of the decree of the sultan, it is the rule that the stone should not be shipped.

In a document dated $21^{\text {st }}$ of October 1866 from the İstanbul French Consulate to the Ottoman Grand Vizier, assistance was requested for Çikaldi - Count Dominique Albert Édouard Tiburce Colonna-Ceccaldi- 1866-1869, French Consul in Cyprus, who wanted to research historical artefacts in some places on the island. ${ }^{75}$ Because this request was considered acceptable, it was necessary that the Ottoman Grand Vizier send an Emirnâme on this matter to the Governor of Cyprus. In this Emirnâme dated $23^{\text {rd }}$ October 1866, sent from the Grand Vizier to the Governor of Cyprus, Consul Çikaldi's request from the French Consulate in Cyprus of researching historical artefacts in some places on the island was recorded. In this Emirnâme, it was emphasized that it was a State tradition that antiquity researchers' leave one, of any pair of figures which had been unearthed to the Imperial Museum and that they could keep the other and the unique ones. On the other hand, the removal was forbidden of those noteworthy markers from antiquity that have been raised in a region, and the different still standing antiquities. If historical artefacts are to be researched in lands that do not belong to the State, it was necessary (for the researcher) to obtain this permission from the respective owners. Only under these conditions, is it ordered not to prevent this antiquities research on the island, and to assist when necessary. As previously announced, if there were historical artefacts (duplicates) to be given to the Imperial Museum, it was ordered that they should be taken and preserved and this situation must be reported. ${ }^{76}$

That there were in place Ottoman regulations concerning antiquities in Ottoman territory is clearly shown from the Ottoman archive documents of the $30^{\text {th }}$ of August, 1852; of the $4^{\text {th }}$ of May 1865, with some of the clauses of the latter very similar to those in the later Âsâr-ı Atîka Nizâmnâme of 1869, and of August-September 1865 and October 1866. The document dated $4^{\text {th }}$ of May 1865 most importantly also explicitly states that this was, the rule that the state has applied for a long time (kaide-i miriye). This Ottoman practice is also indicated by Sultan Abdulaziz's requested from the district governorship of Cyprus for exact information about the subject, concerning the electrum gilded vase from Cyprus that was donated to the Louvre in 1851 by Louis Félicien Joseph Caignart de Saulcy, as to, How the historical artefact was found and was taken away (i.e. removed through diplomatic immunity, or, smuggled from Ottoman Cyprus). It was requested by the Sultan that this be investigated and a report of the incident made in an impartial manner. Sultan Abdulaziz was concerned as to how from his territory this artefact had been smuggled abroad, and wanted to determine which Ottoman subjects were responsible for this. Undoubtedly this was so that the punishment they received could serve as an exemplary lesson to other Ottoman subjects ignoring the longstanding Ottoman practice concerning antiquities, aimed at preventing their illegal excavation and removal from Ottoman territory. These Ottoman archive documents not only clearly indicate Ottoman concern at the highest level with antiquities and into the manner of their illegal removal, but they also raise the question as to when in fact Ottoman regulations-rulings concerning antiquities within Ottoman territory had actually come in effect; together with the implications legal, ethical and otherwise that do need to be drawn concerning the whole matter of their excavation and removal from Ottoman territory without obtaining official permission for this. ${ }^{77}$

\section{Earlier Evidence}

That there was Ottoman ruling-law forbidding the removal of antiquities from Ottoman territory was a fact that was well known by Europeans and those working for them and to Ottoman populations. This was clearly recorded in a letter dated 1623/h.1032 to the Earl of Arundel by the English Ambassador in Istanbul, Thomas Roe, that permission would not be granted $^{78}$ for the removal of antiquities from Ottoman territory, so ambassador Roe relates, antiquities had to be removed secretly, i.e. illegally ${ }^{79}$ and with bribes, ${ }^{80}$ smuggled

\footnotetext{
${ }^{75}$ BOA. HR. MKT. 561/42.

${ }^{76}$ BOA. HR. MKT. 561/42.

${ }^{77}$ In part this problem stems from the position taken by European Christian States that de facto recognition was given to the powerful Ottoman state, but de jure recognition was missing, indicating illegitimacy, the usurpation by the Muslim Ottomans of legitimate ruler-ship; together with matter of the European identification of ancient Greek and Roman culture and then with the remains of the earliest civilisations between the twin rivers, with so-called western civilisation, its origin and themselves. It seems reasonable to think the reason that diggers such as Botta and Layard began excavations without securing permission for this activity from the Ottoman state was because they felt themselves, as Frenchmen and Englishmen, to be the legitimate inheritors of the civilisations of antiquity, not the de facto rulers of the territory in which these remains were located, the Ottomans.

${ }^{78}$ i.e. permission was required, necessary for their removal, as Adolf Michaelis noted, Sir Thomas was indefatigable in asking the necessary permission from the Turkish authorities, though not always with the desired effect (sic. apparently never was legal permission for the removal of antiquities from Ottoman territory given to the ambassador by the Sultan himself, but permission to search for them was obtained from the Captain pasha, although if this permission also included the removal of these from Ottoman territory is quite another matter.). Adolf Theodor F. Michaelis, Ancient Marbles in Great Britain, tr. by C. A. M. Fennell, Cambridge University Press, Cambridge 1882, p.10-11.

${ }^{79}$ As for example the intention to remove illegally the ancient reliefs from the Golden Gate/Port Aurea/Seven Towers, It was agreed that a Turkish priest (mufti?) should denounce the figural sculptures, as opposed to the religion of Mohammed, and so bring about their removal from their conspicuous position. If once they were transferred to another place it would not be difficult to get them out the way. In fact a
} 


\section{CEMIL CELİK}

overseas. ${ }^{81} \mathrm{He}$ also relates in respect to the utility of a document for this purpose that he secured from the Captain Bassa, whose jurisdiction extends to all the islands and sea-ports, for consul Mr. (John) Markham, ${ }^{82}$ concerning the hunt for antiquities, that some things (some antiquities) by him (the Earl of Arundel) required, were impossible to obteyn, as being against their law and customs. ${ }^{83}$ That there was both Ottoman law and custom concerning antiquities was known to the English ambassador and this was clearly recorded in 1623, two hundred and thirty six years before the ÂÂr-ı Atîka Nizâmnâme of 1869. Because some of the antiquities desired by the Earl of Arundel were impossible to obtain, known to be protected by law and custom from removal from Ottoman territory, it seems most probable that both custom and law in this respect dated from the $16^{\text {th }}$ century, if not earlier. This is likewise evident in the case of the arrest in 1624 of the French Consul in Smyrna/İzmir, Sanson Napollon, and the confiscation of the antiquities bought from the Ottoman Cyclades that he had purchased $;{ }^{84}$ as is also indicated in the remarks made by Cornelis de Bruijn at Ephesus in November $1678 .{ }^{85}$ It was also recorded in the $18^{\text {th }}$ century by Richard Chandler, who, like ambassador Roe in May 1623, advocated bribery and secrecy in the removal of antiquities from Ottoman territory, clearly recording in his publication of 1775 that he knew that what he was proposing was an action that was illegal and which he hoped could be induced through the offering of financial prize. ${ }^{86}$ This was the same course of action in respect to the removal of antiquities - secrecy and bribery - that was later recommended by the British consul in 1812 to members of the Society of Friends, concerning the removal of the Bassae Temple frieze from Ottoman territory. ${ }^{87}$ Indications of the Ottoman concern to prevent the removal of antiquities from Ottoman territory except with legal permission are recorded in other travelers' accounts, not least because in the customs house such exports with the permission to export, and which were not the gift of the sultan, were liable for the payment of duty, ${ }^{88}$ which was

priest was engaged for this purpose and a sum of 600 crowns proffered in case of success; a temporary deposit of 500 dollars being actually made by way of preliminary. But even this hope proved elusive. Michaelis, op.cit., p. 14, to get them out the way, meaning to remove them to England.

${ }^{80}$ English Ambassador Sir Thomas Roe to the Porte 1621-1628, in a letter to the Earl of Arundel of May 1623, "On (the) Asia side, about Troy, Zizicum, and all the way to Aleppo, are innumerable pillars, statues, and tombstones of marble, with inscriptions in Greek; these may be fetched at charge and secretly; but if we ask leave, it cannot be obtained; therefore Mr. Markham (English consul) will use discretion, rather than power, and so the Turks will bring." Thomas Roe, The negotiations of Thomas Roe in his Embassy to the Ottoman Porte from the year. 1621-28 inclusive, Society for the Promotion of Learning, London1740, p.154. Discretion, in this case, being a euphemism for bribes. This exact text from ambassador Roe recording the deliberate theft of antiquities from Ottoman territory was repeatedly published in the $19^{\text {th }}$ c. As by Sir Henry Ellis, The British Museum. The Townley Gallery, Vol. I., Charles Knight and Co., London 1836, p.62; Sir Henry Ellis, The Townley Gallery of Classic Sculpture in the British Museum, Vol. I., Nattali and Bond, London 1846, p.62; W. Noël Sainsbury, Original unpublished papers illustrative of the life of Sir Peter Paul Rubens, as an artist and a diplomatist, Bradbury and Evans, London 1859, p.238; Edward Edwards, Lives of the Founders of the British Museum; with notices of its Chief Augmentors and other Benefactors, 1570-1870, Part I., Trübner and Co., London 1870, p.191; Michaelis, op.cit., p.187. The practice of bribery in the theft of antiquities from Ottoman territory was longstanding, the precedent for this repeatedly published and, in 1884 was picked up in the USA in a review of Michaelis, Ancient Marbles in Great Britain: The manner of dealing with the Turkish Government for antiquities, and getting them out of the country, seems to have been much the same in those days as it is now. Sir Thomas writes, in a letter to Lord Arundel dated 1623: On the Asian side...but if we ask leave it cannot be obtained; therefore Mr. Markham will use discretion, rather than power, and so the Turks will bring them for their profit. J. T. C., “Ancient Marbles in Great Britain-II.”, The American Architect and Building News, Vol. XV., No. 426, Feb. 23, 1884, p.91; also Duggan op.cit., p.126, 128-130.

${ }^{81}$ Roe op.cit, p.808, and the difficulty to get our ships to go out of the way to take them (ancient marbles-statues) in, to load at some out of the way place (not via the Ottoman customs house) for shipment to England.

${ }^{82}$ At Smyrna in 1611, then on Chios 2 Sep 1614, to Smyrna at some time before 1620 to after 1623, David Wilson, British Consular Officials in the Ottoman Empire, July $2011 @$ @ http://www.levantineheritage.com > pdf > List_of.

${ }^{83}$ Roe, op.cit, p.54.

${ }^{84}$ Ed. C. Knight, Arts and Sciences: Or, Fourth Division of "The English Encyclopedia, Vol. I., Bradbury, Evans \& Co., London 1866, p.596; P. Gassendus, Englished by W. Rand, The Mirrour of True Nobility and Gentility. Being the Life of The Renowned Nicolaus Claudius Fabricius Lord of Peiresk, Senator of the Parliament at Aix, Bk. IV, London 1657, p.33-34.

85 "We found there (at Ephesus) many marble statutes buried in the ground. However, due to the negligence the feet of some of them were outside. I wanted to unearth one of them during the night and to carry it to Smyrna on a carriage. But, I couldn't find anyone to help me even in return for money because they were afraid of our being watched." http://gallica.bnf.fr/ark:/12148/bpt6k85330k/f71.image . A passage clearly indicating that the local population was aware that this proposed activity was illegal, no assistance was offered for excavation, certainly not at night, and, that attention was being paid by the Ottoman state to prevent the removal of antiquities from its territory, such that the villagers suspected they would be under surveillance at Ephesus.

${ }^{86}$ Richard Chandler, Travels in Asia Minor, Or an Account of a Tour Made at the Expense of the Society of Dilettanti, printed at the Clarendon Press London 1775, p.28, regarding the removal of antiquities, "It is to be wished that a Premium (Prize) were offered, and the undertaking recommended to commanders of ships in the Levant trade. They have commonly interpreters to negotiate for them, with men, leavers, ropes, and other requisites, besides instruments or tools, by which the stone might be broken, if necessary. By a proper application of all-prevailing gold, it is believed they might gain the permission or connivance of the papas and persons concerned. It should be done with secrecy. The experiment is easily made, when they are at Tendos, or wind-bound at the mouth of the Hellespont." The reason for the bribery and secrecy was because it was understood to be breaking Ottoman law.

${ }^{87}$ The English consul was greatly embarrassed when his opinion was sought on the best method of removal (of the newly discovered frieze from Ottoman territory), and recommended either a moonlight flit or bribery, Bracken, op.cit., p.126.

${ }^{88}$ E.g. Dr. Robert Huntingdon recorded in the second half of the $17^{\text {th }}$ century that, having procur'd 4 stones the best mark'd with those figures of Antiquity I could meet with (hieroglyphs), and sent them down to Alexandria, in order to their transportation for England, I found them upon my second Voyage into Egypt very much injur'd, being put into the Custom-house-yard, where they lye still embargoed by the Aga; who demanded an intollerable sum for the liberty to ship them, as you may remember I told you the story. Philosophical Transactions, Giving Some Accompt of the Present Undertakings, Studies, and Labours of the Ingenious in Many Considerable Parts of the World, Vol. XIV., Royal Society of London, Oxford 1684, p.625. The great sum required by the Aga to permit the export of these antiquities may not 


\section{WAS THERE ANTIQUITIES LAW AND REGULATIONS BEFORE THE ÂSÂR-I ATÎKA NIZÂMNÂME OF 1869?}

estimated as a percentage of the estimated value of the antiquity, ${ }^{89}$ and, therefore the duty in $17^{\text {th }}$ century Alexandria's customs-house was quite possibly an intollerable sum, ${ }^{90}$ for four stones carved with hieroglyphs for Dr. Robert Huntingdon to pay, but these antiquities were given substantial value by the Ağa of the customshouse, who was not indifferent to the value of antiquities.

The fact that the Ottoman administration in the $18^{\text {th }}$ century on Cyprus forbade excavation for antiquities on pain of the most rigorous punishment, is clearly recorded by Giovanni Filippo Mariti. ${ }^{91}$ It seems probable that when Robert Wood wrote, we, carried off the marbles whenever it was possible; for the avarice or superstition of the inhabitants made that task difficult and sometimes impractical, ${ }^{92}$ that, in part, the difficulties the party experienced were because removal was forbidden by the Ottoman authorities. Likewise, Charles-NicolasSigisbert Sonnini de Manoncourt, a little later in 1778 clearly states the case, Heaps of ruins to this day occupy the place of one of the most splendid cities of ancient Greece (Cnidus, in S.W. Turkey), and the hand which rules over these remains (the Ottoman official hand) prohibits all approach to them, and does not even allow digging among them, in order to discover fragments of its ancient splendour. ${ }^{93}$ No digging-excavation, as likewise on Milos, at Sifour, where slight, but secret digging, daily brings to light funeral inscriptions, vases, idols, medals etc., ${ }^{94}$ secret digging, because the digging was itself forbidden. The Ottoman forbidding of excavations for antiquities on Cyprus is recorded by John Bramsen in September $1814,{ }^{95}$ and is likewise recorded for the Pashalik of the Morea, at Bassae in 1812, the Turks, who banned all such (antiquarian-treasure hunting ${ }^{96}$ ) activities $;^{97}$ as likewise later, in the summer of 1866 , the Larnaca district governor Cenap Efendi informed the American Consul on Cyprus L. P. Di Cesnola, that the carrying out of excavations without approval was strictly prohibited, and arrested two of the diggers, a position on digging-excavating for antiquities that was confirmed by the islands' governor. ${ }^{98}$ Although Mariti's, Bramsen's and Cesnola's statements, relate the Ottoman customary law forbidding excavations for antiquities on Cyprus, as elsewhere over the course of more than two centuries, G. R. H. Wright writes: First of all it is possible to limit somewhat the body of law applicable. There is nothing to indicate the existence in Cyprus of any custom referring to antiquities. In particular there is no evidence for any qānūn specifying that it was forbidden (yasak) to carry out activities connected with antiquities in Ottoman lands unless in possession of the Sultan's firman authorising such activities. This in itself would have constituted an Antiquities Law sui generis, of which there is no record. ${ }^{99}$ a "useful statement," both wrong and misleading, ${ }^{100}$ as likewise from 2014, Handbook on the Law of Cultural

have been simple veniality, but may well have been because he would have knowingly broken the sultan's rule, and for granting such permission for the export of these antiquities, could have answered with his head.

${ }^{89}$ Export duties are levied by the Turks even upon fragments of ancient works of art, eight per cent being assessed on the assumed value, the determination of which is, of course, in such a case, altogether arbitrary. Clarke, op. cit, p.36

${ }^{90}$ Op. cit. fn. 90.

91 That on Cyprus, "The Turkish government has forbid, under the most rigorous punishment, all subterranean researches (i.e. excavations)..." G. Mariti, Travels Through Cyprus, Syria, and Palestine; with a General History of the Levant, Vol. 1, G. G. J. and J. Robinson, London 1791, 53; also published by P. Byrne, Dublin, 1792, 53. The passage is translated differently in, G. Mariti, Travels in the Island of Cyprus, (Trans. Claude Delaval Cobham), Cambridge at the University Press, Cambridge 1909, p.33, "The Turkish government forbids excavations,..." Perhaps unsurprisingly there was no mention in Cobham's 1909 publication of, under the most rigorous punishment, for undertaking excavations.

${ }^{92}$ Robert Wood, The Ruins of Palmyra, otherwise Tedmor, in the Desart, London 1753, n.p.n.

${ }^{93}$ Charles Sigisbert Sonnini, Travels in Greece and Turkey: Undertaken by Order of Louis XVI, and with the Authority of the Ottoman Court, Vol. I., T. N. Longman \& O. Rees, London 1801, p.189-190.

${ }^{94}$ Idem. Sonnini, Vol. II., 1801, p.245.

${ }^{95}$ In September 1814 John Bramsen records: "There is but little on the island of Cyprus to make the traveller regret his not touching it, although there are great many antiquities around Larneca, yet the jealous Turks (meaning Ottoman officials) will not permit any person to make researches." J. Bramsen, Letters of a Prussian Traveller: Descriptive of a Tour Through Sweden, Prussia, Austria, Hungary, Istria, the Ionian Islands, Egypt, Syria, Cyprus, Rhodes, the Morea, Greece, Calabria, Italy, the Tyrol, the Banks of the Rhine, Hanover, Holstein, Denmark, Westphalia, and Holland, H. Colburn, London 1818, p.303. It seems evident that G. R. H. Wright, "Archaeology and Islamic Law", in Ed. Tatton-Brown, Cyprus in the $19^{\text {th }}$ century AD: Fact, Fancy and Fiction: Papers of the 22nd British Museum Classical Colloquium, December 1998, Oxbow Books, 2001, 263, was unaware, or chose to ignore both Mariti's and John Bramsen's accounts.

${ }^{96}$ 1626, ambassador Roe to the Duke of Buckingham, My agents from Greece are retorned with no great fruit of their labours, other than discoveries of some marbles underground, which will require tyme and privacy to take up, to avoid the envy of these people, who suspect treasure in every place where Christians breake the earth. Roe, op.cit., p. 511.

${ }^{97}$ Soon however, a local official arrived begging them to desist from digging or moving stones (i.e. excavating), since this might bring harm to his village from the Turks, who banned all such activities. C. P. Bracken, Antiquities Acquired, David \& Charles, London 1975 , p.140.

${ }_{98}$ Çelik, op.cit., p.271, Cesnola requested an explanation from the island government and was told that carrying out excavations without approval was strictly prohibited.

${ }_{99}$ Wright, op.cit.,p.263.

${ }^{100}$ This is followed by the following statement, The Ottoman Antiquities Law (Asar i-Atika) was promulgated in 1874 when Lang had ceased his connection with antiquities and Cesnola was about to leave the Island to return to America and install both his collection and himself in the Metropolitan Museum. Wright 2001, 265, as though there was no body Ottoman antiquities law and regulations before 1874! 
Heritage and International Trade, The earliest official attempts to protect Turkeys cultural heritage from damage and destruction were made during the mid-nineteenth century... ${ }^{101}$

\section{CONCLUSION}

The examples of Ottoman documentation revealed here concerning the antiquities of Ottoman territory from the decades before 1869 show Ottoman rules and regulations concerning antiquities were in place and it was stated these were established, were of longstanding - that antiquities were of concern to the sultan - that certain unique ancient marker monuments above ground were not to be touched (were in effect, protected monuments); while in 1862 recorded that the official permissions granted to foreigners to search for antiquities were being abused, that antiquities were being illegally exported from the island in quantity, and in consequence, a total ban on excavations for antiquities on Ottoman territory was required (as had been the case at the start of the century, as earlier), or, at least, far more clearly defined and limited permissions given for officially permitted searches and excavations within the Ottoman territory. While it was recorded in 1623 by the English ambassador to the Porte that antiquities had to be removed without permission, i.e. illegally from Ottoman territory, as legal permission for their removal would not be given. The ambassador also recorded that both Ottoman qānūn and custom were in place in Ottoman territory designed to protect some antiquities from illegal removal, this more than two centuries before 1869. As such was the case, there are simply no grounds for stating that the Ottoman state was indifferent on the matter of antiquities in Ottoman territory until the $19^{\text {th }}$ century. It is beyond any reasonable doubt that there was an Ottoman Antiquities Law sui generis, both law and administrative rules, in effect forbidding the export of antiquities from Ottoman territory ${ }^{102}$, without a decree permitting their export, that existed in the $17^{\text {th }}$ century and which were most probably in effect from the $16^{\text {th }}$ century onwards; while the forbidding within Ottoman territory of excavations undertaken to search for antiquities, unless with official permission, may in origin, likewise date from the $16^{\text {th }}$ century if not before, and such was certainly in force, as is clearly recorded in the $17^{\text {th }} 18^{\text {th }}$ and $19^{\text {th }}$ centuries prior to 1869 . In consequence, there is simply no sound documented historical basis for the statement that has been repeated as though it were a fact for more than thirty years by both Western and Turkish scholars, international lawyers and politicians, that the 'first' Ottoman law on antiquities was the Âsâr-l Atîka Nizâmnâme which came into force on the $13^{\text {th }}$ of February 1869 , or the so-called 'first' of 1874, or that of 1884. It was in part the long established Ottoman rules and regulations, customs, and qānūn including Emirnâme, on the matter of antiquities, of forbidding excavation for them, and forbidding their removal from Ottoman territory, Ottoman established law and practice which was then codified into the Greek national legislation of May 1834, and that of Ottoman Egypt of 1835, that prohibited the excavation for antiquities and the export of antiquities without the necessary permission that already existed in the $17^{\text {th }}$ century in Ottoman territory.

\section{BIBLIOGRAPHY}

\section{Archive Documents}

(BOA.) Presidency of the Republic of Turkey Directorate of State Archives, Ottoman Archives

BOA. A.\} MKT. 39/46.

BOA. A.\} MKT. MVL. 28/70.

BOA. A.\} MKT. UM., 290/30.

BOA. A.\} TŞF. 3/63.

BOA. A.\}TŞF. 10/66.

BOA. HR. MKT. 250/60.

BOA. HR. MKT. 358/34.

\footnotetext{
${ }^{101}$ Blake op.cit., p.438. Janet Blake, “Turkey,” Eds. James A. R. Nafziger, Robert Kirkwood Paterson, Handbook on the Law of Cultural Heritage and International Trade, Edward Elgar, Cheltenham U.K., Northampton, M.A., 2014, p.438.

${ }^{102}$ Interestingly, Edward Daniel Clarke noted there was a total embargo on the removal of antiquities from Ottoman territory by British subjects, one introduced by Sir Robert Ainslie, ambassador to the Porte, 1775-1793, The aid our national situation, with regard to Turkey, might then have afforded, was studiously withheld. An absolute prohibition was in force, respecting the removal of any of the antiquities of the country, excepting by the agents of our own ambassador to the Porte, Edward Daniel Clarke, Travels in Various Countries of Europe, Asia, and Africa, Part the Second, Greece, Egypt and the Holy Land, T. Cadell and W. Davies, London 1812, p.211.
} 


\section{WAS THERE ANTIQUITIES LAW AND REGULATIONS BEFORE THE ÂSÂR-I ATÎKA NIZÂMNÂME OF 1869?}

BOA. HR. MKT. 401/24.

BOA. HR. MKT. 483/58.

BOA. HR. MKT. 525/47.

BOA. HR. MKT. 532/40, (6.).

BOA. HR. MKT. 561/42.

BOA. İ.DH. 257/15845.

BOA. İ.ŞD. 11/547 (4.).

BOA. MVL. 794/57.

BOA. VGG. d. 386, 577/1.

(MAA) (Cyprus National Archive and Research Centre Documents/Kyrenia/TRNC) KŞS. (Kıbrıs Şer'iyye Sicili-Cyprus Shari’a Court Registers)

KŞS. 41, 116/1.

\section{Published Sources}

ADAIR, Robert, The Negotiations for the Peace of the Dardanelles: In 1808-9: with Dispatches and Official Documents, Vol. I., Longman, Brown, Green and Longman, London 1845.

ANDERSON, Benjamin, "An alternative discourse": Local interpreters of antiquities in the Ottoman Empire", Journal of Field Archaeology, 40/4, 2015, pp.450-460.

Arts and Sciences: Or, Fourth Division of "The English Encyclopedia, Conducted by Charles Knight, Vol. I., Bradbury, Evans \& Co., London 1866.

AYAR, Mesut, "XIX. Yüzyılın İkinci Yarısında Tuzla (Larnaka): Ticaret, Ticaret Mahkemesi ve Konsolosluklar", Histories of Ottoman Larnaca, Eds. Evangelia Balta-Theoharis Stavrides-Ioanis Theocharides, The Isis Press, İstanbul 2012, pp.347-380.

BALFOUR, Patrick, Europa Minor: Journeys in Coastal Turkey, Lord Kinross, John Murray, London 1956.

BARROW, Isaac, A Treatise of the Pope's Supremacy, Swords, Stanford, and Co., New York 1834.

BELZONI, Giovanni Battista, Narrative of the Operations and Recent Discoveries Within the Pyramids, Temples, Tombs, and Excavations in Egypt and Nubia, H. Remy, Brussels 1835.

BLAKE, Janet, "Turkey,", Eds. James A. R. Nafziger, Robert Kirkwood Paterson, Handbook on the Law of Cultural Heritage and International Trade, Edward Elgar, Cheltenham U.K., Northampton, M.A., 2014, pp.437459.

BLAKE, Janet, International Cultural Heritage Laws, Oxford University Press, Oxford 2015.

BRACKEN, C. P., Antiquities Acquired, David \& Charles, London 1975.

BRAMSEN, J., Letters of a Prussian Traveller: Descriptive of a Tour Through Sweden, Prussia, Austria, Hungary, Istria, the Ionian Islands, Egypt, Syria, Cyprus, Rhodes, the Morea, Greece, Calabria, Italy, the Tyrol, the Banks of the Rhine, Hanover, Holstein, Denmark, Westphalia, and Holland, H. Colburn, London 1818.

C., J. T., "Ancient Marbles in Great Britain-II.”, The American Architect and Building News, Vol. XV., No. 426, Feb. 23, 1884, pp.89-92.

CASSON, Stanley, Cypre dans l'antiquite, Payot, Paris, 1939.

CESNOLA, Luigi Palma di, Cyprus: Its Ancient Cities, Tombs, and Temples: A Narrative of Researches and Excavations During Ten Years' Residence as American Consul in that Island, John Murray, London 1877. 


\section{CEMIL CELİK}

CHANDLER, Richard, Travels in Asia Minor, Or an Account of a Tour Made at the Expense of the Society of Dilettanti, printed at the Clarendon Press, London 1775.

CLARKE, Edward Daniel, Travels in Various Countries of Europe, Asia, and Africa, Part the Second, Greece, Egypt and the Holy Land, T. Cadell and W. Davies, London 1812.

CLARKE, Edward Daniel, Travels in Various Countries of Europe, Asia, and Africa, Part the Second, Greece, Egypt and the Holy Land, T. Cadell and W. Davies, London 1817.

CLARKE, Joseph Thatcher, Report on the Investigations at Assos, Papers of the Archaeological Institute of America: Classical series, Vol. II., 1882, 1883, Part I. Macmillan Co., New York 1898.

COHEN, Ada, Steven E. Kangas, Assyrian Reliefs from the Palace of Ashurnasirpal II: A Cultural Biography, Hood Museum of Art, Dartmouth College, Hanover, NH., 2010.

COOK, Brian F., Bernard Ashmole, Donald Emrys Strong, Relief Sculpture of the Mausoleum at Halicarnassus, Trustees of the British Museum, Oxford University Press, Oxford 2005.

ÇAL, Halil, “Osmanlı Devleti’nde Âsâr-1 Atika Nizâmnâmeleri”, Vakıflar Dergisi, 26, 1997, pp. 391-400.

ÇELIK, Cemil, "The American Consul Cesnola Brothers and the Fate of Antiquities in Ottoman Cyprus", Bingöl Üniversitesi Sosyal Bilimler Enstitüsü Dergisi, 22, 2021, pp.265-296.

D'ATHANASI, Giovanni, A Brief Account of the Researches and Discoveries in Upper Egypt, Made Under the Direction of Henry Salt: To which is Added a Detailed Catalogue of Mr. Salt's Collection of Egyptian Antiquities... for the British Museum, John Hearne, London 1836.

DIAZ-ANDREU, Margarita, "From Nineteenth-Century New Imperialism to Twentieth-Century Decolonization", Eds., Bonnie Effros, Guolong Lai, Unmasking Ideology in Imperial and Colonial Archaeology: Vocabulary, Symbols, and Legacy, University of California, Los Angeles 2018, pp.3-28.

DUGGAN, T. M. P., “On early antiquarians in Asia Minor to the start of the 19th century”, Gephyra, 17, 2019, pp.115-167.

EDWARDS, Edward, Lives of the Founders of the British Museum; with notices of its Chief Augmentors and other Benefactors, 1570-1870, Part I., Trübner and Co., London 1870.

ELDEM, Edhem, "From Blissful indifference to Anguished Concern: Ottoman Perceptions of Antiquities, 17991869”, Eds. Z. Bahrani, Zeynep Çelik, Edhem Eldem, Scramble for the Past: A Story of Archaeology in the Ottoman Empire, 1755-1914, SALT/Garanti Kültür A.Ş., Istanbul 2011, pp.281-330.

ELLIS, Henry, The British Museum. The Townley Gallery, Vol. I., Charles Knight and Co., London 1836.

ELLIS, Henry, The Townley Gallery of Classic Sculpture in the British Museum, Vol. I., Nattali and Bond, London 1846.

GASSENDUS, P., Englished by W. Rand, The Mirrour of True Nobility and Gentility. Being the Life of The Renowned Nicolaus Claudius Fabricius Lord of Peiresk, Senator of the Parliament at Aix, Bk. IV, London 1657.

GIBBON, Edward, The History of the Decline and Fall of the Roman Empire, Vol. XII., A. Strahan, London 1790 .

GLIDDON, George Robins (Late U.S. consul at Cairo), A Memoir on the Cotton of Egypt, James Madden and Co., London 1841.

GLIDDON, George Robins, Ancient Egypt: Her Monuments, Hieroglyphics, History and Archoeology, and Other Subjects Connected with Hieroglyphical Literature, Wm. Taylor and Co., New York 1847.

HALL, Johnathan M., Artifact and Artifice: Classical Archaeology and the Ancient Historian, University of Chicago Press, Chicago and London 2014.

HUGHES, T. S., "An Address To the People of England in the Cause of the Greeks occasioned by The Late Inhuman Massacres in the Isle of Scio, etc", The Pampleteer; Dedicated to Both Houses of Parliament, Vol. XXI., London 1822, pp.167-188.

JEFFERY, George, A description of the Historic Monuments of Cyprus. Studies in the Archaeology and Architecture of the Island, Dalcassian Publishing Company, Nicosia, Cyprus 1918. 


\section{WAS THERE ANTIQUITIES LAW AND REGULATIONS BEFORE THE ÂSÂR-I ATÎKA NIZÂMNÂME OF 1869?}

LANE-POOLE, Stanley, The Life of the Right Honourable Stratford Canning: Viscount Stratford de Redcliffe, Vol. II., Longmans, Green and Co., London, New York 1888.

LELORRAIN, M., "A Journey in Egypt and Observations of the Circular Zodiac of Denderah by M. Saulnier", Voyages and Travels: Consisting of Originals and Translations, Vol. VIII. Richard Phillips, London 1822, pp.75-96.

LUKE, Christina, A Pearl in Peril: Heritage and Diplomacy in Turkey, Oxford University Press Oxford 2019.

MALCOLM, Noel, Useful Enemies: Islam and The Ottoman Empire in Western Political Thought, 1450-1750, Oxford University Press, Oxford 2019.

MARANA, Giovanni Paolo, The Eight Volumes of Letters Writ by a Turkish Spy, who Liv'd Five and Forty Years Undiscover'd at Paris: Giving an Impartial Account to the Divan at Constantinople of the Most Remarkable Transactions of Europe: and Discovering Several Intrigues and Secrets of the Christian Courts, (especially of that of France) Continued from the Year 1637, to the Year 1682, Vol. IV., G. Strahan, London 1718.

MARINDIN, G. E., (Ed.), The Letters of John B. S. Morritt of Rokeby Descriptive of Journeys in Europe and Asia Minor in the Years 1794-1796, John Murray, London 1914.

MARITI, G., Travels in the Island of Cyprus, (Trans. Claude Delaval Cobham), Cambridge: at the University Press, 1909.

MARITI, G., Travels Through Cyprus, Syria, and Palestine; with a General History of the Levant, Vol. 1, London, G. G. J. and J. Robinson, 1791, also published by P. Byrne, Dublin 1792.

MATTHERS, John M., “Excavations by the Palestine Exploration Fund at Tell El-Hesi 1890-1892”, Ed. B. T. Dahlberg- K. G. O'Connell, S.J., Tell El-Hesi: The Site and the Expedition, EISENBRAUNS, Winona Lake, Indiana 1989, pp.37-62.

MERRILLEES, Robert Stuart, Kiely Thomas, "The Archaeological Interests Of Samuel Brown, Government Engineer, And His Circle Of Acquaintances In Late 19th Century Cyprus", Cahiers du Centre d'Etudes Chypriotes, 42, 2012, pp. 245-272.

MERRILLEES, Robert Stuart, "Studies on the Provenances of the Stele of Sargon II From Larnaca (Kition) and the Two So-Called Dhali (Idalion) Silver Bowls in the Louvre", Cahiers du Centre d'Etudes Chypriotes, 46, 2016, pp.349-386.

MICHAELIS, Adolf Theodor F., Ancient marbles in Great Britain, tr. by C. A. M. Fennell, Cambridge University Press, Cambridge 1882.

NEWTON, Charles Thomas, Travels and Discoveries in the Levant, Vol. II., Day and Son, Ltd., London 1865.

NIKOLAOU, Polina, "Archeology, Empire and the Field: Exploring the Ancient Sites of Cyprus, 1865-1876", Eds. Diarmid A. Finnegan, Jonathan Jeffrey Wright, Spaces of Global Knowledge: Exhibition, Encounter and Exchange in an Age of Empire, Routledge, London-New York 2016, pp.39-56.

Parliamentary Papers, Appendix to Report from the Select Committee on Miscellaneous Expenditure, H.M. Stationery Office, London 1848.

PAYNE, Emma M., Casting the Parthenon Sculptures from the Eighteenth Century to the Digital Age, Bloomsbury, London, New York 2021.

Philosophical Transactions, Giving Some Accompt of the Present Undertakings, Studies, and Labours of the Ingenious in Many Considerable Parts of the World, Vol. XIV., Royal Society of London, Oxford 1684.

POCOCKE, Richard, A Description of the East, and Some Other Countries, Vol. II. Part II., Observations..., W. Bowyer, London 1745.

RAYNAL, Abbé (Guillaume-Thomas-François), A Philosophical and Political History of the Settlements and Trade of the Europeans in the East and West Indies, Trans. J. O. Justamond, Vol. VIII., W. Strahan \& T. Cadell, London 1783. 


\section{CEMIL CELİK}

ROE, Thomas, The negociations of Thomas Roe in his Embassy to the Ottoman Porte from the year. 1621-28 inclusive, Society for the Promotion of Learning, London 1740.

ROSENSTEIN, Leon, Antiques: the History of an Idea, Cornell University Press, New York 2009.

SAINSBURY, W. Noël, Original unpublished papers illustrative of the life of Sir Peter Paul Rubens, as an artist and a diplomatist, Bradbury and Evans, London 1859

SCHLIEMANN, Heinrich, Ilios: The City and Country of the Trojans: the Results of Researches and Discoveries on the Site of Troy and Throughout the Troad in the Years 1871-72-73-78-79: Including an Autobiography of the Author, John Murray, London 1880.

SERWINT, Nancy, 'Review: Cyprus in the 19th Century AD: Fact, Fancy and Fiction: Papers of the 22nd British Museum Classical Colloquium, December 1998 by Veronica Tatton-Brown,' Bulletin of the American Schools of Oriental Research, No. 337, Feb., 2005, pp.109-112.

SHAW, Wendy M. K., Possessors and Possessed: Museums, Archaeology, and the Visualization of History in the Late Ottoman Empire, Berkley: University of California Press, 2003.

SLATTER, Enid, Xanthus, Travels of Discovery in Turkey, Rubicon Press, London 1994.

SONNINI, Charles Sigisbert, Travels in Greece and Turkey: Undertaken by Order of Louis XVI, and with the Authority of the Ottoman Court, Vol. I., T. N. Longman \& O. Rees, London 1801.

SU, Kamil, Osman Hamdi Bey’e Kadar Türk Müzesi, ICOM Türkiye Milli Komitesi Press, Istanbul 1965.

Testimonies of Different Authors Respecting the Colossal Statue of Ceres: Placed in the Vestibule of the Public Library at Cambridge, July the First, 1803; with a Short Account of Its Removal from Eleusis, November 22, 1801, Printed by Francis Hodson, Cambridge 1803.

“The Cesnola Collection”, Harper's Weekly, Vol. XXI, No. 1046, Supplement, Jan. 13, New York 1877, pp.3839.

The English Review, Or, An Abstract of English and Foreign Affairs, Nov. London 1787.

THOMPSON, Jason, Wonderful Things: A History of Egyptology, Vol. II., Oxford University Press, Oxford 2015.

TRAMPIER, Joshua R., Landscape Archaeology of the Western Nile Delta, Lockwood Press, Atlanta, Georgia 2014.

VAUX, William Sandys Wright, On Recent Excavations at Cyrene by Lieutenant R. M. Smith, R. E., Transactions of the Royal Society of Literature, London 1863.

VYSE, Howard, Operations carried on at the pyramids of Gizeh in 1837, Vol. II., James Fraser, London 1840.

WALSH, R., Account of the Levant Company, London 1825. Translation of the Italian copy of this firman by William St. Clair, Lord Elgin and the Marbles, Oxford 1983.

WATERFIELD, Gordon, Layard of Nineveh, John Murray, London 1963.

WESTCOAT, Bonna D., The Temple of Athena at Assos, Oxford University Press, Oxford 2012.

WILSON, William Rae, Travels in the Holy Land, Egypt, \&c. \&c., Vol. II., Longman, Rees, Orme, Brown, and Green, London 1831.

WOOD, John Turtle, Discoveries at Ephesus: Including the Site and Remains of the Great Temple, James R. Osgood and Co., Boston 1877.

WOOD, Robert, An Essay on the Original Genius and Writings of Homer: With a Comparative View of the Ancient and Present State of the Troade, T. Payne, P. Elmsly, London 1775.

WOOD, Robert, The Ruins of Palmyra, otherwise Tedmor, in the Desart, The Publisher To The Reader, London 1753. 


\section{WAS THERE ANTIQUITIES LAW AND REGULATIONS BEFORE THE ÂSÂR-I ATÎKA NIZÂMNÂME OF 1869?}

WRIGHT, G. R. H., “Archaeology And Islamic Law In Ottoman Cyprus”, Ed. Veronica Tatton-Brown, Cyprus in the 19th Century AD: Fact, Fancy and Fiction: Papers of the 22nd British Museum Classical Colloquium, December 1998, Oxbow Books, 2001, pp.261-266.

WRIGHT, G. R. H., "The Legality Of The Consular Excavations In Ottoman Cyprus", Ed. Veronica TattonBrown, Cyprus in the 19th Century AD: Fact, Fancy and Fiction: Papers of the 22nd British Museum Classical Colloquium, December 1998, Oxbow Books, 2001, pp.1-11.

\section{Online Sources}

https://collections.louvre.fr/ark:/53355/c1010171082_accessed:11.6.2021.

https://gallica.bnf.fr/ark:/12148/bpt6k85330k/f71.image accessed: 24.3.2021.

https://collections.louvre.fr/en/ark:/53355/c1010171082 accessed: 08.06.2021.

http://www.levantineheritage.com/pdf/List_of_British_Consular_Officials_Turkey(1581-1860)-D_Wilson.pdf accessed: 23.09.2021. 


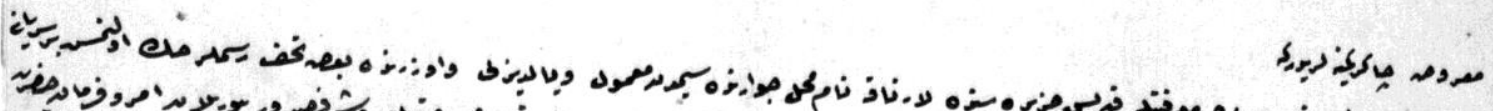

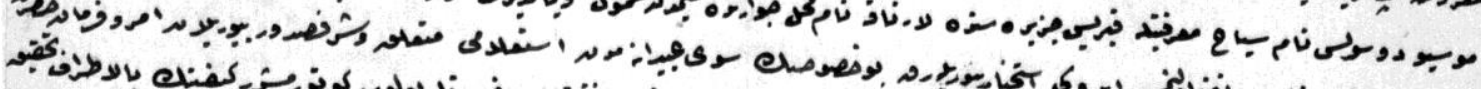

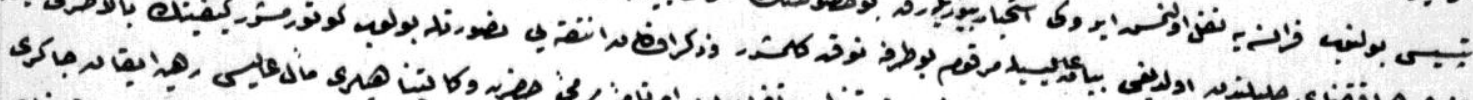

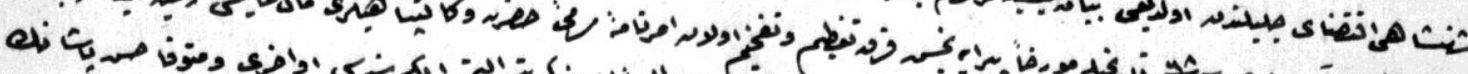

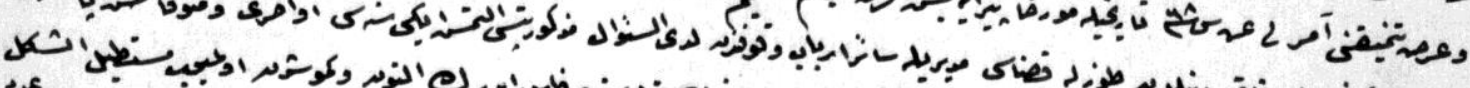

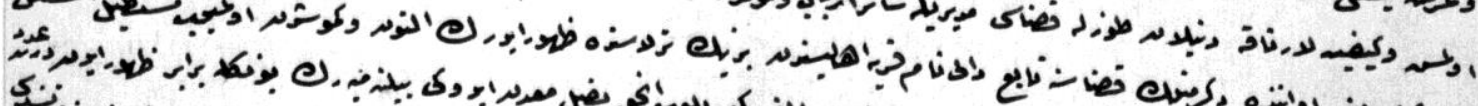

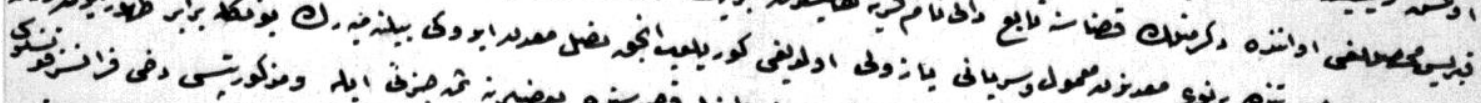

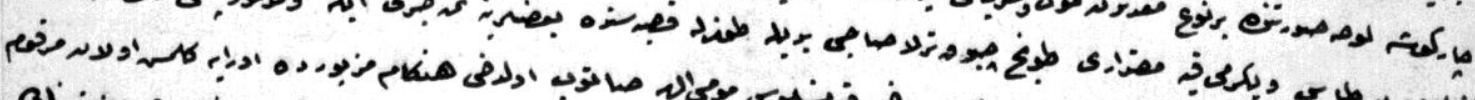

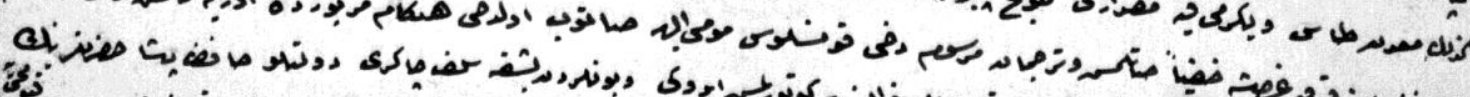

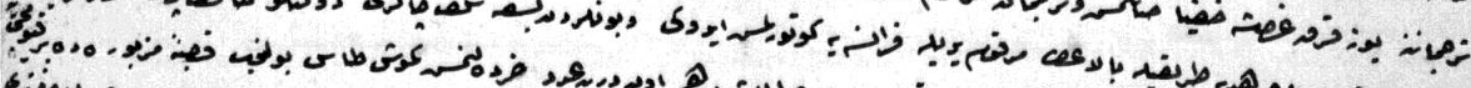

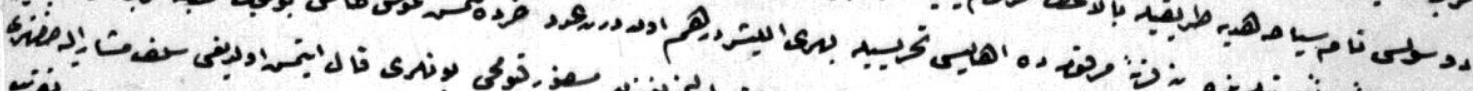

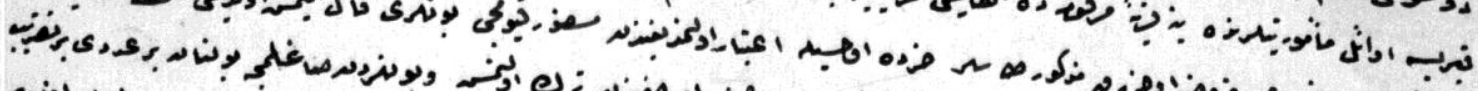

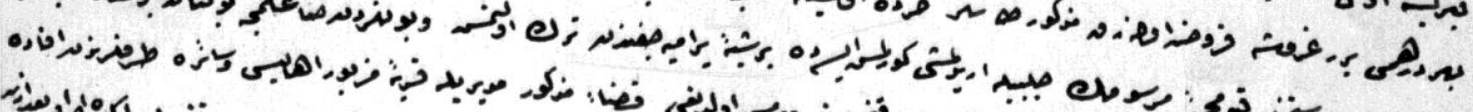

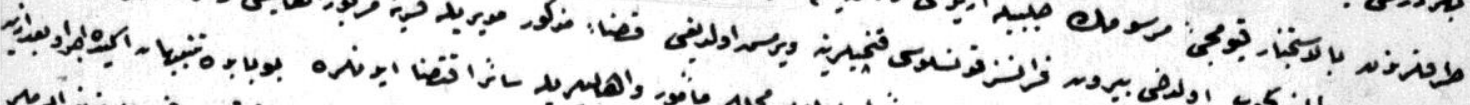

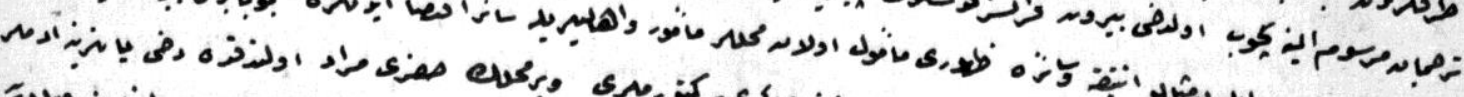

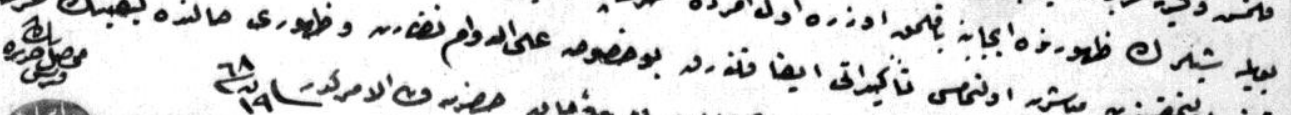

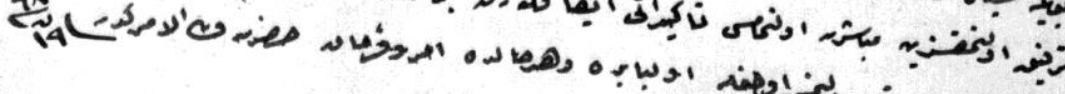

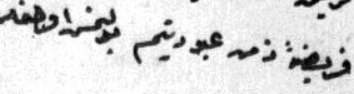

i. $D H+257 / 15845$

\section{İ.DH.00257}

Annex-1 


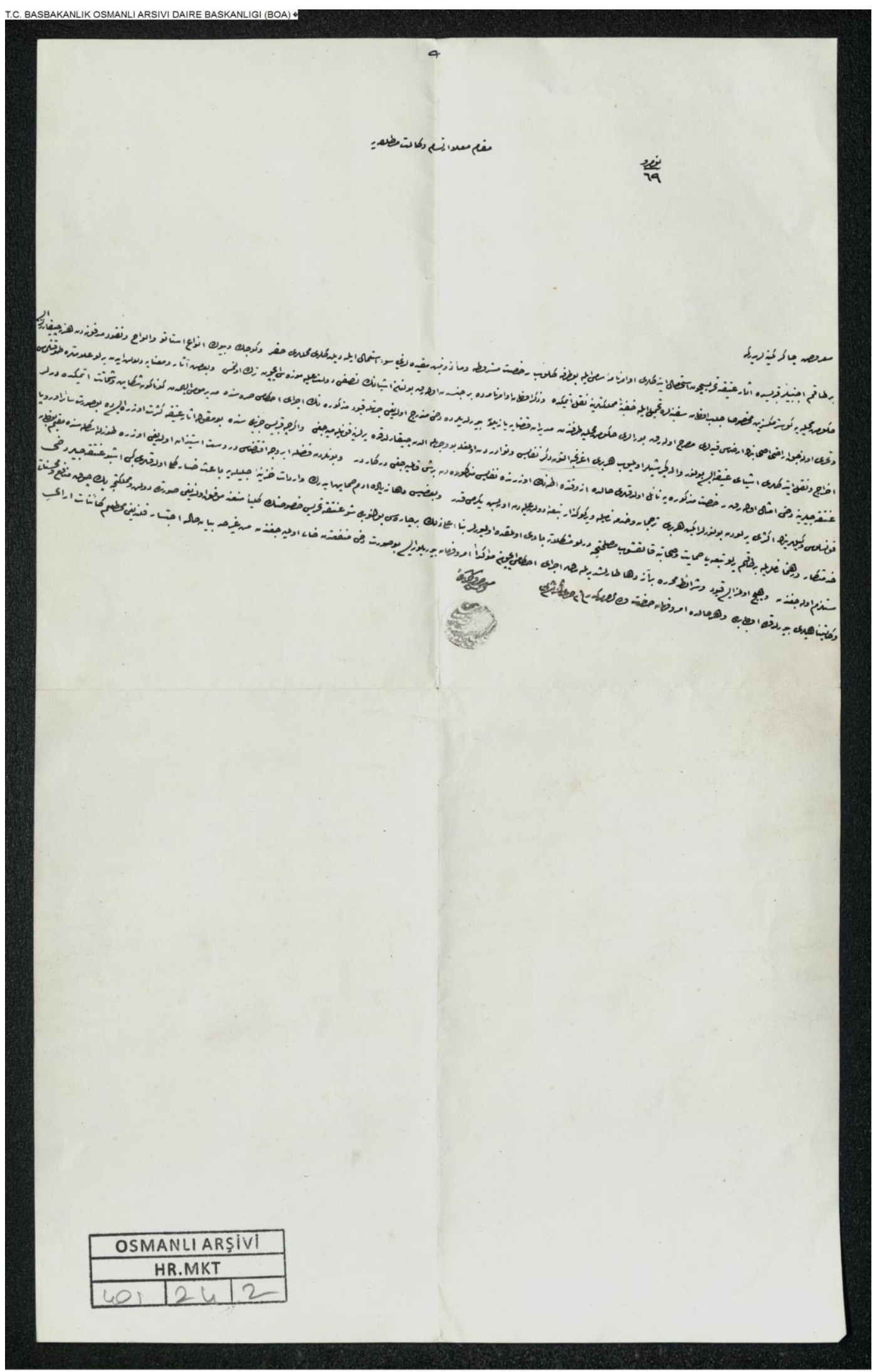

HR.MKT.00401.00024.002

Annex-2 